\title{
Calpain-Mediated N-Cadherin Proteolytic Processing in Brain Injury
}

\author{
You-Na Jang, ${ }^{1,2,3}$ Yi-Sook Jung, ${ }^{1}$ Soo Hwan Lee, ${ }^{1,3}$ Chang-Hyun Moon, ${ }^{1,3}$ Chang-Hoon Kim, ${ }^{1,3}$ and Eun Joo Baik ${ }^{1,2,3}$ \\ ${ }^{1}$ Department of Physiology, ${ }^{2}$ Chronic Inflammatory Disease Research Center, and ${ }^{3}$ BK 21 Graduate Program for Medical Sciences, Ajou University School of \\ Medicine, Suwon 443-749, Korea
}

\begin{abstract}
Neural-cadherin (N-cadherin), a member of the classical cadherin family of transmembrane glycoproteins, mediates cellular recognition and cell-cell adhesion through calcium-dependent homophilic interactions and plays important roles in the development and maintenance of the nervous system. Metalloproteinase is known to cleave N-cadherin, which is further cleaved by $\gamma$-secretase. The intracellular domain of $\mathrm{N}$-cadherin interacts with $\beta$-catenin, and $\beta$-catenin stability is critical for cell-cell adhesion and cell survival. In the present study, we showed that $\mathrm{N}$-cadherin is cleaved specifically by calpain, resulting in the generation of a novel $110 \mathrm{kDa}$ fragment. The cleavage occurred in ischemic brain lesions and in vitro neural cells in the presence of NMDA and ionomycin, and was restored by calpain inhibitors but not matrix metalloproteinase or $\gamma$-secretase inhibitors. Calpain directly cleaved $\mathrm{N}$-cadherin in in vitro calpain assays, and calpain inhibitors prevented its cleavage in a dose-dependent manner. Using $\mathrm{N}$-cadherin deletion mutants, we found that calpain cleavage sites exist in at least four regions of the cytoplasmic domain. Treatment with NMDA induced neuronal death, and it suppressed the expression of surface $\mathrm{N}$-cadherin and the $\mathrm{N}$-cadherin/ $\beta$-catenin interaction, effects that were prevented by calpain inhibitor. Furthermore, calpain-mediated $\mathrm{N}$-cadherin cleavage significantly affected cell-cell adhesion, AKT signaling, the $\mathrm{N}$-cadherin/ $\beta$-catenin interaction and the Wnt target gene expressions through the accumulation of nuclear $\beta$-catenin.
\end{abstract}

\section{Introduction}

Cadherins play critical roles in the establishment of adherenstype junctions by mediating calcium-dependent cell-cell adhesion. Neural-cadherin (N-cadherin) is a member of the classical cadherin family of transmembrane glycoproteins, which mediates cellular recognition via a calcium-dependent homophilic binding mechanism (Takeichi, 1990). In the nervous system, $\mathrm{N}$-cadherin has been implicated in several key events required for cell migration, axonal guidance, and synaptic plasticity (Matsunaga et al., 1988; Inoue and Sanes, 1997). The cytoplasmic domain of cadherin interacts with $\beta$-catenin, a structural adaptor linking to the cytoskeleton for cell-cell adhesion (Okabe et al., 2003).

Recently, several reports have shown that the cleavage of $\mathrm{N}$-cadherin is regulated by several proteases. In particular, the matrix metalloproteinase (MMP) ADAM 10 is responsible for the initial proteolytic processing of $\mathrm{N}$-cadherin, leading to the generation of the approximate $40 \mathrm{kDa} \mathrm{C}$-terminal fragment termed CTF1 (Reiss et al., 2005). The fragment is further pro-

\footnotetext{
Received Dec. 29, 2008; revised April 9, 2009; accepted April 10, 2009.

This study was supported by a 2004 grant from Department of Medical Sciences, Graduate School, Ajou University, and by the Korea Science and Engineering Foundation through Chronic Inflammatory Disease Research Center (KOSEF R-13-2003-019-01005-0). We thank Dr. Zhen-Ge Luo (Institute of Neuroscience, Shanghai Institutes of Biological Sciences, Chinese Academy of Sciences, Shanghai, China) and Dr. Lisa M. Ellerby (Buck Institute for Age Research, Novato, CA) for providing $\mathrm{p} 35$ and calpain 5 constructs, respectively.

Correspondence should be addressed to either of the following: Dr. Eun Joo Baik or Dr. Chang-Hoon Kim, Department of Physiology, Ajou University School of Medicine, Suwon 443-749, Korea, E-mail: eunjoo@ajou.ac.kr or Changhoon@yahoo.com.

DOI:10.1523/JNEUROSCI.6178-08.2009

Copyright $\odot 2009$ Society for Neuroscience ～0270-6474/09/295974-11\$15.00/0
}

cessed by $\gamma$-secretase-like activity, producing the soluble $35 \mathrm{kDa}$ CTF2 (Marambaud et al., 2003). Accordingly, Uemura et al. (2006a, 2006b) demonstrated that ADAM 10-mediated ectodomain shedding is a prerequisite for the subsequent PS $1 / \gamma$ secretase-mediated $\varepsilon$-cleavage, which is a constitutive process. The $\varepsilon$-cleavage of $\mathrm{N}$-cadherin activates the nuclear $\beta$-catenin movement essential for cell survival, tissue repair, and transcriptional activation, as shown in Alzheimer's disease (Parisiadou et al., 2004; Reiss et al., 2005; Uemura et al., 2006a).

Activation of the NMDA receptor, an ionotropic glutamate receptor, results in a calcium influx into cells. This calcium influx activates a variety of enzymes, including the calcium-dependent protease calpain (Siman et al., 1989). Calpain is a ubiquitous calcium-sensitive protease essential for normal neuronal function, such as long-term potentiation (Tomimatsu et al., 2002). In addition, calpain is pathologically activated by $\mathrm{Ca}^{2+}$ influx in cerebral ischemia (Lankiewicz et al., 2000), traumatic brain injury (Wang et al., 2006), and many neurological diseases, including Alzheimer's disease (Saito et al., 1993), Parkinson's disease (Crocker et al., 2003), and amyotrophic sclerosis (Strong et al., 2001). Under these pathological conditions, calpain cleaves a number of neuronal substrates essential for neuron survival. For example, the neuron-specific activator of cyclin-dependent kinase 5 (cdk5), p35, is a well known calpain substrate (Kusakawa et al., 2000; M. S. Lee et al., 2000; Patzke and Tsai, 2002; Wang et al., 2007). The calpain-mediated cleavage of p35 to p 25 is involved in the pathogenesis of Alzheimer's disease, and the calpainmediated p35 cleavage pathway may serve as a target for pharmacological intervention (Patrick et al., 1999; M. S. Lee et al., 2000). Thus, the exogenous regulation of calpain activity is of interest 
A

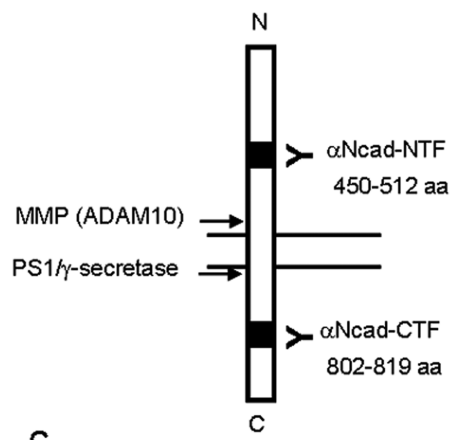

C

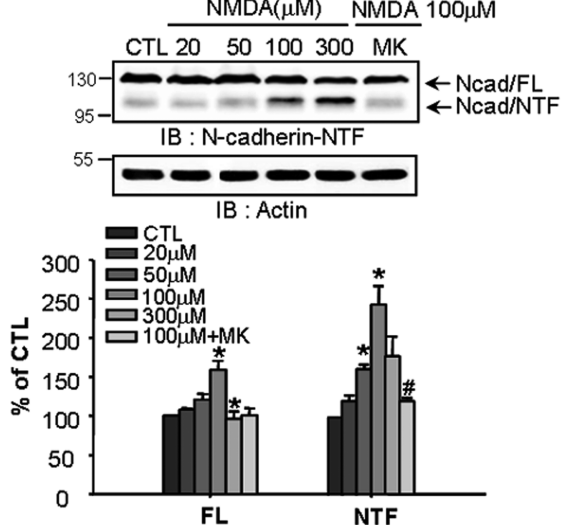

B
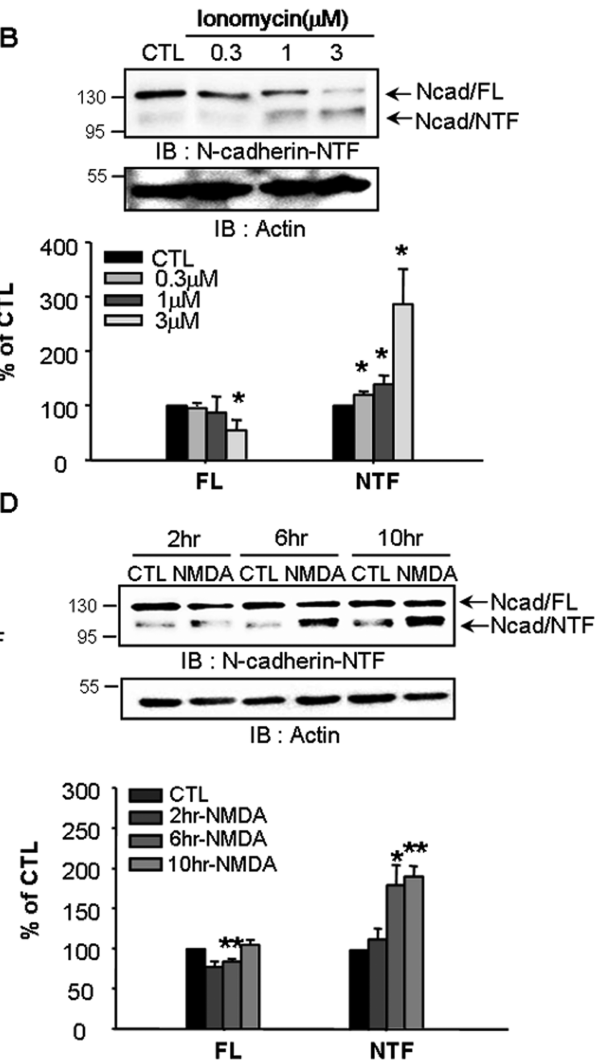

Figure 1. NMDA receptor-induced calcium influx increases $\mathrm{N}$-cadherin cleavage. $\boldsymbol{A}$, Schematic representation of $\mathrm{N}$-cadherin cleavage sites and antibody binding domains. MMP and PS1/ $\gamma$-secretase cleaves the extracellular and intracellular domains of $\mathrm{N}$-cadherin, respectively. We used two different anti-N-cadherin antibodies that recognized the NTF (residues 450 -512) and (TF (residues $802-819$ ) residues. $\boldsymbol{B}$, lonomycin induced N-cadherin cleavage in cortical neurons in a dose-dependent manner. Cells were treated with ionomycin for $30 \mathrm{~min}$ and further cultured with fresh media for $8 \mathrm{~h}$. C, The involvement of NMDA receptormediated calcium influx in N-cadherin cleavage. NMDA receptor antagonist MK-801 (MK, $10 \mu \mathrm{M})$ reduced NMDA-induced cleavage. $\boldsymbol{D}, \mathrm{N}$-cadherin was cleaved in a time-dependent manner after NMDA stimulation. Lower panels show the quantitative assessment of full-length $\mathrm{N}$-cadherin (Ncad/FL) and the cleaved N-terminal fragment (Ncad/NTF). Values represent the mean \pm SEM $\left({ }^{*} p<0.05\right.$ vs control, ${ }^{* *} p<0.01$ vs control, $\# p<0.05$ vs $100 \mu$ M NMDA treatment).

for the development of therapeutics to prevent pathological diseases.

In the present study, we elucidated the mechanism by which calpain specifically cleaves $\mathrm{N}$-cadherin after NMDA receptor activation or ischemic injury. We also determined whether calpainmediated $\mathrm{N}$-cadherin cleavage regulates cell-cell adhesion, cell signaling, interactions with $\beta$-catenin, and cellular $\beta$-catenin signaling.

\section{Materials and Methods}

Reagents and antibodies. We used rabbit polyclonal anti-N-cadherin antibody (s.c.-7939) against the extracellular (NTF) domain of N-cadherin (Santa Cruz Biotechnology), which was raised against human amino acids 450-512 that map within the extracellular domain. We also used mouse monoclonal anti- $\mathrm{N}$-cadherin antibody (clone 32 ) against the intracellular (CTF) domain of N-cadherin (BD Biosciences), which was generated from mouse $\mathrm{N}$-cadherin amino acids $802-819$. In addition, mouse monoclonal $\beta$-catenin antibody (BD Biosciences), anti-green fluorescent protein (GFP; Invitrogen), anti- $\beta$-actin (Sigma), anti- $\beta$ tubulin (BD Biosciences), and anti-histone H1 (Santa Cruz Biotechnology) antibodies were obtained. Anti-p-AKT and anti-AKT antibodies were purchased from Cell Signaling Technology. The NMDA and 1, 10-phenanthroline were purchased from Sigma. Ionomycin, calpeptin, MDL 28170, GM 6001, DAPT ( $\gamma$-secretase inhibitor IX), and purified human erythrocyte $\mu$-calpain (calpain I) were purchased from Calbio-

chem. The MK-801 (dizocilpine maleate, $(+)-$ MK801 maleate) was purchased from Tocris Bioscience.

Cell culture and transfection. Procedures with pure cortical neuron cultures and astrocyte cultures were previously described (Kwon et al., 2005). For pure cortical neuron cultures, the brain from a 14-d-old Institute of Cancer Research (ICR) mouse embryo was isolated. Cells were used after $7 \mathrm{~d}$ in vitro, when the majority of cells were neurons and no glial elements were detectable. For astrocyte cultures, cerebral cortices were isolated from 1-d-old postnatal ICR mouse brains. Cells were used after $14 \mathrm{~d}$. Treatment was 100 or $300 \mu \mathrm{M}$ NMDA applied for 30 $\mathrm{min}$. After $30 \mathrm{~min}$ incubation, the medium was replaced with fresh medium lacking NMDA, and the cultures were further incubated before analysis. All inhibitors were added $30 \mathrm{~min}$ before NMDA treatment. For transfections, different DNA constructs were transfected into COS-7 cells or SK-N-MC cells for 24 or $48 \mathrm{~h}$ using Lipofectamine 2000 (Invitrogen) according to the manufacturer's protocol.

In vitro calpain assay. The mouse brain cortex was homogenized in extraction buffer (50 mм HEPES, pH 7.5, 1 mм EGTA, 50 mм KCl, 2 $\mathrm{mm} \mathrm{MgCl}_{2}$, and $5 \mathrm{~mm}$ mercaptoethanol) containing protease inhibitors but no leupeptin. The homogenate was centrifuged at $1000 \times g$ for $10 \mathrm{~min}$ at $4^{\circ} \mathrm{C}$, and the resulting supernatant (crude membrane) was collected. The supernatant was incubated at $30^{\circ} \mathrm{C}$ with purified human erythrocyte $\mu$-calpain (calpain I) in extraction buffer, with or without $1 \mathrm{~mm} \mathrm{CaCl}_{2}$. The SDS sample buffer (62.5 mu Tris-HCl, pH 6.8, 4\% SDS, $10 \%$ glycerol, $50 \mathrm{~mm}$ DTT, and $0.1 \%$ bromophenol blue) was added to stop the reaction, and the sample was boiled at $100^{\circ} \mathrm{C}$ for $10 \mathrm{~min}$. Before the assay was carried out, we validated the assay using the known substrates of calpain, such as $\beta$-catenin cleavage (Benetti et al., 2005; Rios-Doria and Day, 2005; Abe and Takeichi, 2007; Lee et al., 2008), p35 processing (Patrick et al., 1999; Kusakawa et al., 2000; Lee et al., 2000), and clearance of the full-length N-cadherin (supplemental Fig. S1, available at www. jneurosci.org as supplemental material).

DNA constructs. The p35-myc and Flag-tagged calpain were generous gifts from Dr. Zhen-Ge Luo (Institute of Neuroscience, Shanghai Institutes of Biological Sciences, Chinese Academy of Sciences, Shanghai, China) and Dr. Lisa M. Ellerby (Buck Institute for Age Research, Novato, $\mathrm{CA})$, respectively. The mouse $\mathrm{N}$-cadherin clone was purchased from the Korea Research Institute of Bioscience and Biotechnology. The fulllength $\mathrm{N}$-cadherin (N-cad 906) was obtained by PCR and cloning into the pEGFP-N1 vector. The sequence was verified by sequencing. To create $\mathrm{N}$-cadherin deletion mutants (N-cad 750, 760, 771, 790, 801, and 839), PCR-amplified N-cadherin fragments were digested with EcoRI/ XhoI and inserted into the EcoRI/XhoI sites of the pEGFP-N1 vector. Internal deletion mutants $(\Delta 771-801, \Delta 771-839, \Delta 790-839$, and $\Delta 801-839)$ were generated by sequential ligations at the XhoI, EcoRI, and SmaI sites of the 1-771/801-906, 1-771/839-906, 1-790/839-906, and 1-801/839-906 clones, respectively. The oligonucleotides used in PCR were as follows: N-cad 750 forward, 5'-CAGAATTCGATCCCGCCGTTTCATCCATACCAC-3'; N-cad 760 forward, 5'-CAGAATTCGAATTAAAAGCTGCTTGGCTTGGCG-3'; N-cad 771 forward, 5'-CAGAATTCGCAATATATTATCTCTTACATCATC-3'; N-cad 790 forward, 5'-CAGAATTCGGAGCTGGCTCAAGTCATAGTCCTG-3'; $\mathrm{N}$-cad 801 forward, 5'-CAGAATTCGGATGGCATCAGGCTCCACAGTATC-3'; N-cad 839 forward, 5'-CAGAATTCGGCCCTCATTA- 
A

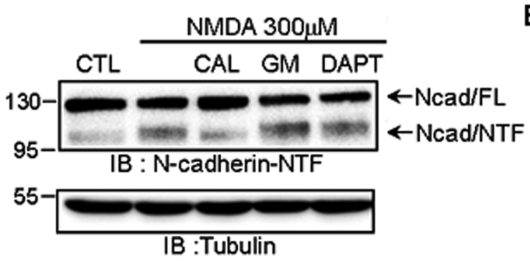

D

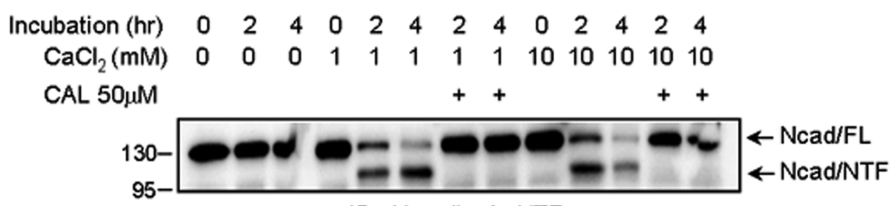

IB : N-cadherin-NTF

F

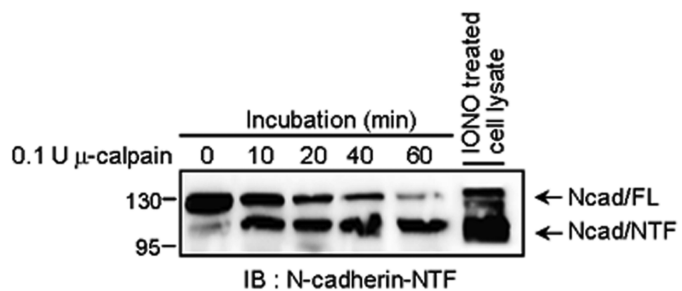

B

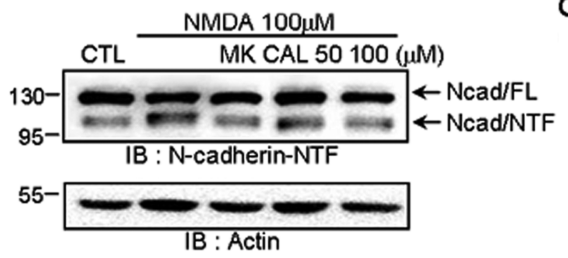

E $1 \mathrm{mM} \mathrm{CaCl}{ }_{2}$ $50 \mu \mathrm{M} \mathrm{CAL}$ $10 \mu \mathrm{M}$ GM 10 $\mu \mathrm{M}$ DAPT $10 \mu \mathrm{M}$ E 64 20 $\mu \mathrm{M}$ Z-VAD-FMK c
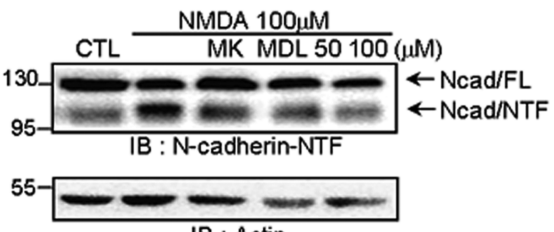

IB : Actin
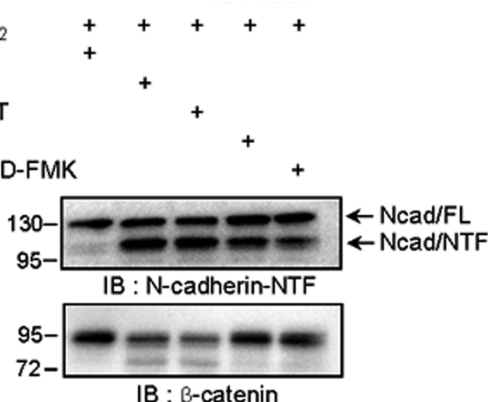

G

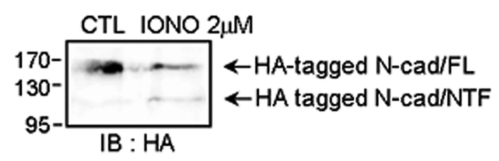

Figure 2. Calpain is responsible for N-cadherin cleavage. $A$, Calpain inhibitor, but not inhibitors of MMP or $\gamma$-secretase, reduced N-cadherin NTF generation during NMDA treatment. The Western blots are representative of four independent experiments. $\boldsymbol{B}$, C, Calpain inhibitors reduced NMDA-dependent NTF cleavage. $10 \mu \mathrm{m}$ MK-801 or calpain inhibitor (CAL) in $\boldsymbol{B}$ or MDL 28170 (MDL) in $\boldsymbol{C}$ was added for $8 \mathrm{~h}$. D, The requirement for calcium and calpain in N-cadherin cleavage in vitro. Mouse brain lysates were incubated with different concentrations of $\mathrm{CaCl}_{2}$ for the indicated times in the absence or presence of the calpain inhibitor CAL. E, Calpain was the main protease to cleave N-cadherin in brain lysates. Calpain, cysteine protease, and caspase cleaved $\beta$-catenin. Brain lysates were incubated with $1 \mathrm{~mm} \mathrm{CaCl} 2$ for $4 \mathrm{~h}$ in the presence of calpain inhibitor, the MMP inhibitor GM 6001 (GM), $\gamma$-secretase inhibitor DAPT, cysteine protease inhibitor E64, or caspase inhibitor Z-VAD-FMK. $\boldsymbol{F}$, The time-dependent cleavage of $\mathrm{N}$-cadherin by purified $\mu$-calpain in the brain membrane fraction. The $110 \mathrm{kDa}$ (NTF) fragments of $\mathrm{N}$-cadherin found in the brain membrane fraction were identical to those in ionomycin-treated cortical neurons (IONO treated cell lysate). G, Calcium influx generated $110 \mathrm{kDa}$ fragments of N-terminal HA-tagged N-cadherin, which was transfected into COS-7 cells. The cells were treated with or without $2 \mu \mathrm{m}$ ionomycin (IONO) for $10 \mathrm{~min}$ and further cultured with fresh media for $2 \mathrm{~h}$. The Western blots are representative of four independent experiments. CAL, Calpeptin; GM, GM 6001.

ATGAAGTCCCCAAT-3'; N-cad 906 forward, 5'-GGCTCGAGATGTGCCGGATAGCGGGAGCGCCGCGGACC-3'; reverse for all deletion mutants, 5'-GGCTCGAGATGTGCCGGATAGCGGGAGCGC CGCGGACC-3'; $\Delta 771-801$ forward, 5'-CAGAATTCGGATGGCATCAGGCTCCACAGTATC-3'; $\Delta 771-839$ and $\Delta 801-839$ forward, 5'-CAGAATTCGGCCCTCATTAATGAAGTCCCCAAT-3'; and reverse for internal deletion mutants, 5'-ATCCCGGGCGTCACCACCGCCGTACATGTC-3'. All mutants were verified by DNA sequencing.

Western blot analysis. Treated cells were washed twice with ice-cold PBS and harvested in RIPA buffer $\left(150 \mathrm{~mm} \mathrm{NaCl}, 10 \mathrm{mM} \mathrm{Na}_{2} \mathrm{HPO}_{4}, \mathrm{pH}\right.$ $7.2,0.5 \%$ sodium deoxycholate, and $1 \%$ Nonidet P-40) containing $5 \mathrm{~mm}$ EDTA, $10 \mu \mathrm{g} / \mathrm{ml}$ leupeptin, $0.5 \mathrm{~mm}$ phenylmethylsulfonyl fluoride (PMSF), $1 \mu \mathrm{g} / \mathrm{ml}$ pepstatin, and $10 \mu \mathrm{g} / \mathrm{ml}$ aprotinin. Cell lysates were further homogenized by brief sonication. Cell lysates were centrifuged at $14,000 \times g$ for $20 \mathrm{~min}$ at $4^{\circ} \mathrm{C}$ and the resulting supernatant collected. Protein concentrations were determined using BCA reagent. For the quantification of the chemiluminescent signals, PVDF membranes were scanned with a Fuji Film LAS-1000 system and analyzed using Image Gauge software (version 3.12). Brain tissues were prepared as previously described (Jin et al., 2006). The brain was isolated and stored at $-70^{\circ} \mathrm{C}$ overnight, then homogenized in $1 \mathrm{ml}$ of ice-cold buffer containing $50 \mathrm{~mm}$ Tris-HCl, pH 7.4, 1 mm sodium orthovanadate, $150 \mathrm{~mm} \mathrm{NaCl}, 1 \%$ Triton X-100, 5 mм EDTA, $0.5 \%$ sodium deoxycholate, $0.1 \%$ SDS, $1 \mathrm{~mm} \mathrm{MgCl}_{2}$, and protease inhibitors. Homogenates were centrifuged at $15,000 \times g$ for $30 \mathrm{~min}$ at $4^{\circ} \mathrm{C}$. Supernatants were collected and protein concentrations determined using BCA reagent.

Subcellular fractionation. Nuclear fractions were prepared as previously described (Marambaud et al., 2003) with minor modifications. Briefly, treated cells were washed twice with ice-cold PBS and placed in buffer A (10 mm Tris-HCl, pH 7.5, 0.25 м sucrose, 1 mm EDTA) containing protease inhibitors. The cells were then passed through a 27 -gauge needle $\sim 10-15$ times. The cell lysates were centrifuged at $1000 \times g$ for 10 min and the pellet washed with PBS containing $0.1 \%$ Triton X-100. The pellet was then solubilized by brief sonication in RIPA buffer and used as the nuclear fraction.

Biotinylation assay. The surface and internalized (endocytosis) biotinylation assay was performed as previously described (Tai et al., 2007). After NMDA treatment at $37^{\circ} \mathrm{C}$ for the indicated time, the cells were rinsed twice with prechilled PBS. Surface biotin group was removed by incubating with $50 \mathrm{~mm}$ glutathione solution ( $50 \mathrm{~mm}$ reduced glutathione, $75 \mathrm{~mm} \mathrm{NaCl}, 10 \mathrm{~mm}$ EDTA, pH 7.5, 1\% BSA, and $0.075 \mathrm{~N} \mathrm{NaOH}$ ) twice for $15 \mathrm{~min}$ on ice. For surface biotinylation, surface proteins were labeled with sulfo-NHS-SS-biotin and then quenched. Cells were lysed with RIPA buffer containing protease inhibitors. Biotinylated proteins were isolated by incubation with streptavidin-agarose resin (Pierce) for $4 \mathrm{~h}$ at $4^{\circ} \mathrm{C}$. The biotinylated proteins were separated and analyzed by SDS-PAGE.

Immunoprecipitation. Cells were lysed on ice in RIPA buffer containing protease inhibitors. After centrifugation for $20 \mathrm{~min}$ at $13,000 \times \mathrm{g}$ at $4^{\circ} \mathrm{C}$, anti-N-cadherin antibody against the NTF (extracellular) was added to the supernatant and incubated with protein A beads overnight at $4^{\circ} \mathrm{C}$. The beads were washed three times with RIPA buffer, and the immunoprecipitated proteins were subjected to SDS-PAGE and Western blotting.

Immunofluorescence. Cells were washed three times with ice-cold PBS, fixed with ice-cold $4 \%$ PFA for $30 \mathrm{~min}$, and then blocked with 3\% BSA in PBS for $1 \mathrm{~h}$. The cells were incubated with anti-N-cadherin-NTF (extracellular) antibody overnight at $4{ }^{\circ} \mathrm{C}$ and then sequentially permeabilized with $0.1 \%$ Triton X-100 in PBS. Anti- $\beta$-catenin antibody was added and the cells incubated overnight at $4^{\circ} \mathrm{C}$. The cells were incubated for $2 \mathrm{~h}$ with secondary antibodies and mounted on a glass slide with VECTASHIELD (Vector Lab). Images were acquired with a Zeiss LSM 510 confocal microscope (Carl Zeiss).

Focal cerebral ischemia model. All animal protocols were done in accordance with the guidelines on the use and care of laboratory animals set by the Animal Care Committee at Ajou University. Focal cerebral isch- 
A

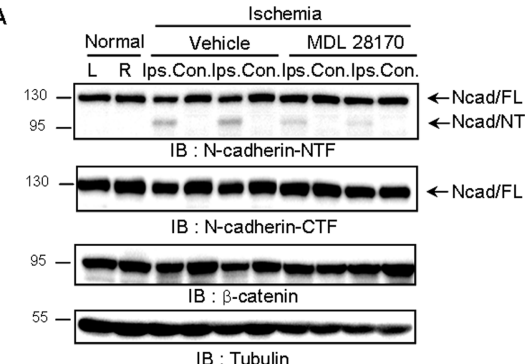

B
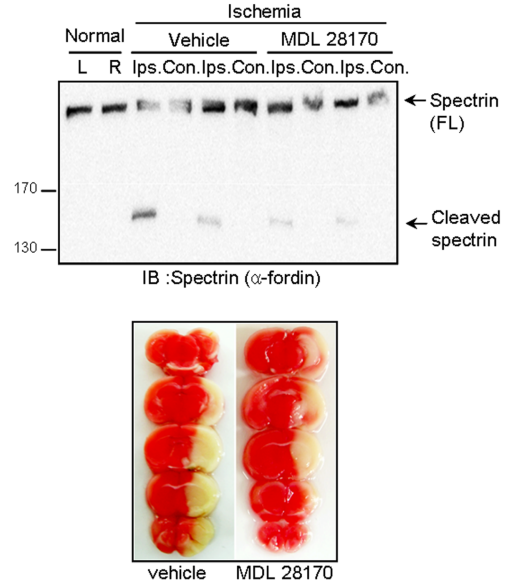
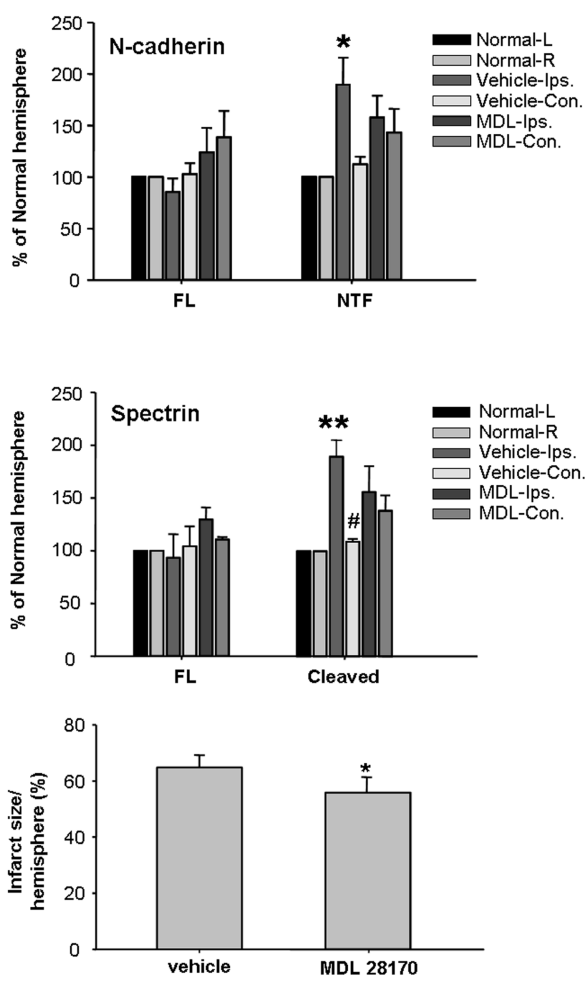

Figure 3. Calpain is responsible for $\mathrm{N}$-cadherin cleavage in ischemic brain injury. $\boldsymbol{A}, \boldsymbol{B}, \mathrm{MDL} 28170$ profoundly suppressed the cleavage of the calpain specific substrate spectrin $(\boldsymbol{A})$, and the generation of $110 \mathrm{kDa}$ N-cadherin NTF $(\boldsymbol{B})(n=4)$. $\boldsymbol{C}$, Effect of MDL 28170 on in vivo ischemia-induced cerebral infarct $(n=5)$. Ischemic brain injury was induced by middle cerebral artery occlusion (MCA0) for $1 \mathrm{~h}$ followed by reperfusion for $24 \mathrm{~h}$. The protocol for MDL injection was described in Materials and Methods. The NTF of N-cadherin was detected with anti-N-cadherin-NTF antibody. L, Left; R, right; Contra, contralateral; Ipsilat, ipsilateral.

emia was induced by occlusion of the left middle cerebral artery (MCA) using an intraluminal filament technique (Hara et al., 1997) based on modifications of the original rat model (Longa et al., 1989). Through a midline neck incision, the left common and external carotid arteries were isolated and ligatured with a 5-0 silk suture (Ethicon). A microvascular clip was temporarily placed across the internal carotid artery. An arteriotomy was fashioned in the common carotid artery just proximal to the carotid bifurcation. A 6-0 nylon monofilament, blunted at the tip with an open flame, was introduced through this incision into the internal carotid artery and advanced $\sim 13 \mathrm{~mm}$ distal to the carotid bifurcation for occlusion of the origin of the MCA. The thread was carefully withdrawn $60 \mathrm{~min}$ after MCA occlusion. After $24 \mathrm{~h}$ reperfusion, the animals were reanesthetized and decapitated. The brains were coronally cut into five 2 $\mathrm{mm}$ slices using a brain matrix. These slices were immediately stained with $2 \%$ 2, 3, 5-triphenyltetrazolium chloride (TTC) for $\sim 30 \mathrm{~min}$. The regions showing red-stained (noninfarcted), and unstained (infarcted) tissue were outlined on each color image and measured using Photoshop and TINA software (KAIST Biotech).

To show the calpain-specific cleavage of $\mathrm{N}$-cadherin in the ischemic brain, $20 \mathrm{mg} / \mathrm{kg}$ MDL 28170, a specific calpain inhibitor, was intravenously administered via tail vein $30 \mathrm{~min}$ after the initiation of ischemia. The MDL $28170(3.33 \mathrm{mg} / \mathrm{kg} / \mathrm{hr})$ was further infused $6 \mathrm{~h}$ after initial injection (Markgraf et al., 1998).

Cell dissociation assay. The cell dissociation assay was performed as previously described (Nagafuchi et al., 1994; Fukata et al., 2002) with minor modifications. Briefly, confluent cultures of astrocytes, C2C12 cells and SK-N-MC cells were incubated with 0.01\% trypsin in HCMF solution ( $137 \mathrm{~mm} \mathrm{NaCl}, 5 \mathrm{~mm} \mathrm{KCl,} 0.33 \mathrm{~mm} \mathrm{Na}_{2} \mathrm{HPO}_{4}, 5.6 \mathrm{~mm}$ glucose, and $10 \mathrm{~mm}$ HEPES, pH 7.4) for $10 \mathrm{~min}$ at $37^{\circ} \mathrm{C}$. Detached cells were incubated with $2 \mathrm{mM} \mathrm{CaCl}_{2}$ (TC treatment) or 2 mM EGTA, pH 7.5 (TE treatment) for $15-30 \mathrm{~min}$ at $37^{\circ} \mathrm{C}$ and dissociated by pipetting 10 times. The number of particles was counted as cell clusters and single cells. The

extent of cell dissociation was represented by the index $\mathrm{N}_{\mathrm{TC}} / \mathrm{N}_{\mathrm{TE}}$, where $\mathrm{N}_{\mathrm{TC}}$ and $\mathrm{N}_{\mathrm{TE}}$ are the total number of particles after TC and TE treatment, respectively. Because cadherin-mediated adhesion is preserved after TC but not TE treatment, the value of $\mathrm{N}_{\mathrm{TC}}$ is expected to be smaller than that of $\mathrm{N}_{\mathrm{TE}}$.

$R T-P C R$. Total RNA was extracted using Easy blue (Intron). The synthesis of cDNAs synthesis was performed using $1 \mu \mathrm{g}$ of total RNA and AMV reverse transcriptase (Roche). First-strand cDNAs were subsequently used for PCR analysis (PerfectShot Ex Tag Kit TaKaRa) with the following primers: 5'-GTGAAGGTCGGTGTGAAC-

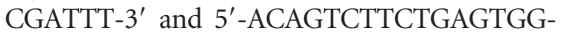
CAGTGAT-3' for Gapdh; 5'-CGGCTTTGATCTCTGCTTAA-3' and 5'-ACAGGTCTCCTCCGTCTTGA-3' for cyclin D1; 5' -GTGACCCTATGCCAACAGAC- $3^{\prime}$ and 5'-TGGCCCATACAAATGACTCT-3' for $L 1$; and $5^{\prime}$-AGATCAGCAACAACCGCAAGT- $3^{\prime}$ and 5' -TCAACTGTTCTCGTCGTTTCC-3' for $c$-myc.

Cell viability. The NMDA cytotoxicity was evaluated by a colorimetric assay using 3-[4, 5-dimethylthiazol-2-yl]-2, 5-diphenyltetrazolium bromide (MTT). The $5 \mathrm{mg} / \mathrm{ml}$ MTT solution was added to cells grown in 24well plates. After incubation with MTT solution for $2 \mathrm{~h}$ at $37^{\circ} \mathrm{C}$, the culture medium was removed. Cells were incubated in solubilization buffer $(0.5 \mathrm{~N} \mathrm{HCl}, 5 \%$ acetic acid, 50\% DMF; $\mathrm{pH} 7.4$ ) overnight at $37^{\circ} \mathrm{C}$. The optical density of each well was measured at $540 \mathrm{~nm}$.

Statistical analysis. All data were expressed as mean \pm SEM from at least three different experiments. The comparisons were made with Student's $t$ tests. A $p$ value of $<0.05$ was considered significant.

\section{Results \\ NMDA receptor-induced calcium influx increases \\ $\mathrm{N}$-cadherin cleavage}

To identify the cleavage sites in the extracellular or intracellular domains of $\mathrm{N}$-cadherin, two different antibodies against $\mathrm{N}$-cadherin were used (Fig. $1 A$ ). $\mathrm{N}$-cadherin is known to be cleaved as a result of calcium influx (Reiss et al., 2005). As shown in Figure $1 B$, activation of calcium influx by the calcium ionophore ionomycin significantly increased the generation of the $110 \mathrm{kDa}$ fragment, the NTF of N-cadherin in a dose-dependent manner. In general, NMDA is thought to activate ionotropic glutamate receptors that induce excess $\mathrm{Ca}^{2+}$ influx in neurons (Boldyrev, 2000). To determine whether $\mathrm{N}$-cadherin cleavage is associated with NMDA-mediated $\mathrm{Ca}^{2+}$ influx, cortical neurons were incubated with NMDA. This treatment significantly increased N-cadherin cleavage in time- and dose-dependent manners (Fig. $1 C, D$ ). The $\mathrm{N}$-cadherin cleavage induced by $100 \mu \mathrm{M}$ NMDA was reversed by the NMDA receptor antagonist MK-801 (Fig. 1C), demonstrating that the NMDA receptor regulates $\mathrm{N}$-cadherin cleavage.

\section{Calpain is responsible for $\mathrm{N}$-cadherin cleavage}

To identify the enzyme responsible for the cleavage of $\mathrm{N}$-cadherin NTF, we tested calpain, MMP and $\gamma$-secretase inhibitors. The $110 \mathrm{kDa} \mathrm{N}$-cadherin fragment resulting from cleavage by NMDA was significantly reduced in the presence of the calpain inhibitor calpeptin $(87.29 \pm 2.47$ of control value compared with 
$108 \pm 1.30$ in $300 \mu \mathrm{M}$ NMDA-treated group; $p<0.01)$. However, the MMP inhibitor GM 6001 (104.01 \pm 1.81 of control value) and $\gamma$-secretase inhibitor DAPT (106.44 \pm 0.91 of control value) had no inhibitory effect on the cleavage of $\mathrm{N}$-cadherin (Fig. 2A). Calpain is a calcium-dependent protease activated by NMDA receptor activation (Vanderklish and Bahr, 2000). To determine whether calpain is involved in NMDA-induced $\mathrm{N}$-cadherin cleavage in neurons, treatment with cell-permeable calpain inhibitors, calpeptin (105.63 \pm 9.68 of control value in $50 \mu \mathrm{M} \mathrm{CAL}$, and $92.90 \pm 12.39$ in $100 \mu \mathrm{M}$ CAL compared with $123.59 \pm 6.86$ in $100 \mu \mathrm{M}$ NMDA-treated group; $p<$ $0.05)$, and MDL 28170 (83.72 \pm 13.97 in $50 \mu \mathrm{M}$ MDL; $p<0.05$, and $61.64 \pm 15.05$ in $100 \mu \mathrm{M} \mathrm{MDL} ; p<0.01)$ reduced $\mathrm{N}$-cadherin cleavage in a dose-dependent manner (Fig. $2 B, C$ ).

To confirm the $\mathrm{N}$-cadherin cleavage by calpain, we performed in vitro calpain assays using the mouse brain homogenate. The fragmentation of $\mathrm{N}$-cadherin was increased in incubation time- and calcium dose-dependent manners, whereas calpeptin, a calpain inhibitor, reversed these effects (Fig. 2D). In addition, $\mathrm{N}$-cadherin cleavage was abrogated by calpeptin but not the MMP inhibitor GM 6001, $\gamma$-secretase inhibitor DAPT, cysteine protease inhibitor E 64, or caspase inhibitor Z-VAD-FMK (Fig. 2E), indicating that calpain acts as a dominant protease for cleaving $\mathrm{N}$-cadherin specifically in neurons. To determine whether purified calpain cut $\mathrm{N}$-cadherin in vitro, we incubated membrane lysates from mouse brain with recombinant $\mu$-calpain. The $\mu$-calpain cleaved full-length $\mathrm{N}$-cadherin into the 110 $\mathrm{kDa}$ fragment obtained in ionomycin-treated cortical neurons (Fig. 2F).

The fragment may come from either extra- or intracellular cleavage of $\mathrm{N}$-cadherin. To address this uncertainty, we used COS-7 cells with N-terminal HA- and C-terminal GFP-tagged N-cadherin. The $110 \mathrm{kDa}$ fragment was detected with anti-HA antibody (Fig. 2G) but not anti-GFP antibody (see Fig. $4 B$ ) after calpain activation, providing strong evidence that calpain cleaves the intracellular but not the extracellular domain of $\mathrm{N}$-cadherin. In addition, intracellular, but not extracellular, calcium chelation reduced NMDA-mediated $\mathrm{N}$-cadherin cleavage, presumably because of a reduction in calpain activity (supplemental Fig. S2, available at www. jneurosci.org as supplemental material). Together, these data indicate that calpain produces the $110 \mathrm{kDa}$ NTF by cutting the intracellular domain of $\mathrm{N}$-cadherin.

\section{Calpain is responsible for $\mathrm{N}$-cadherin cleavage in ischemic brain injury}

In response of ischemic insult, glutamate is released into the extracellular space, increases in neuronal intercellular $\mathrm{Ca}^{2+}$
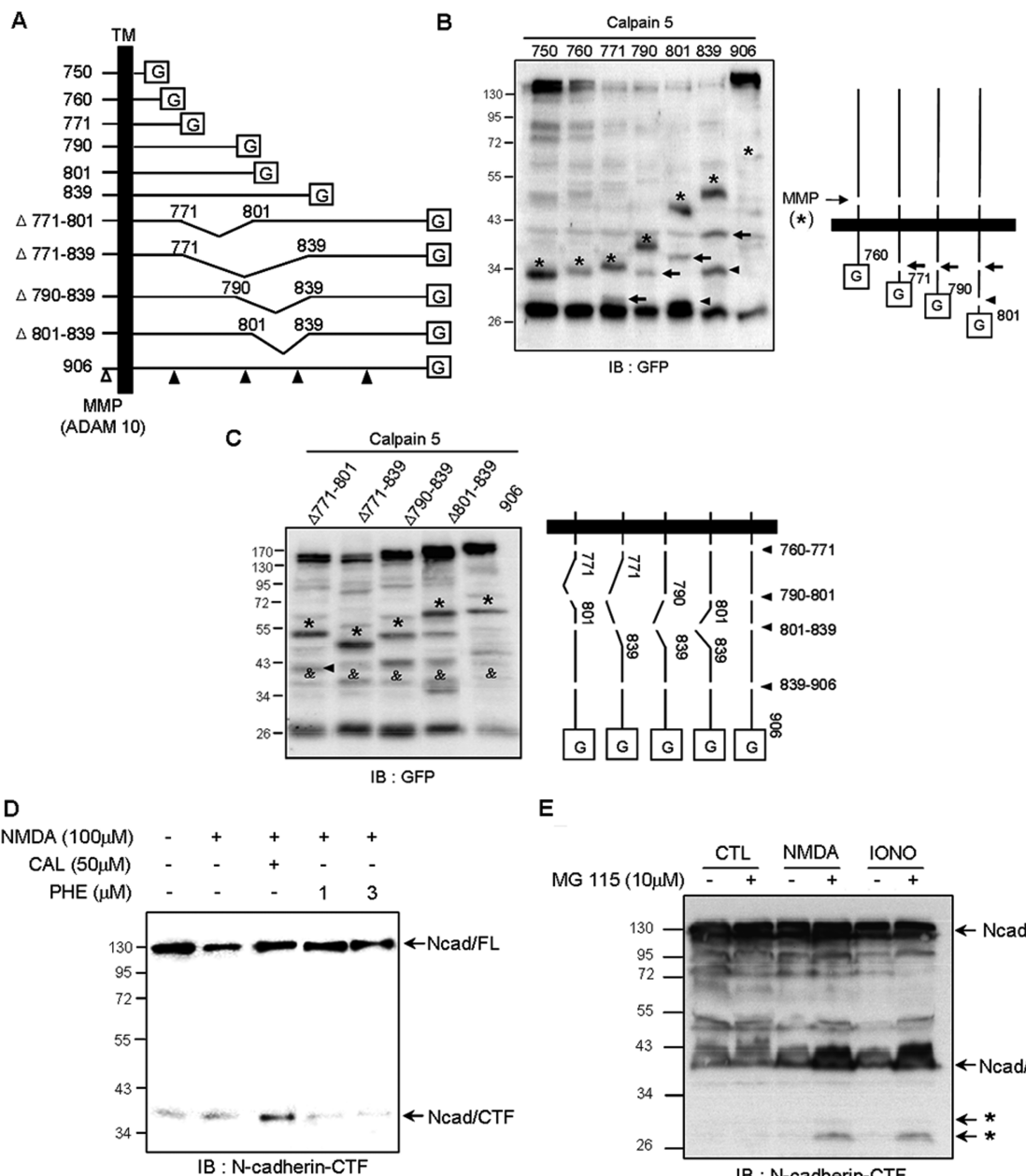

E

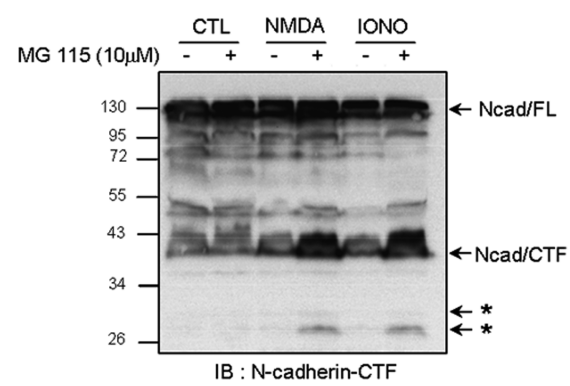

IB : N-cadherin-CTF

Figure 4. Identification of the $\mathrm{N}$-cadherin cleavage sites. $\boldsymbol{A}$, Schematic representation of $\mathrm{N}$-cadherin mutants lacking various amino acid residues $(750,760,771,790,801,839, \Delta 771-801, \Delta 771-839, \Delta 790-839$, and $\Delta 801-839)$ and wild-type with or without the proteasome inhibitor MG 115. The CTF of N-cadherin was detected with anti-N-cadherin-CTF antibody.

through NMDA receptor activation, and finally triggers deleterious cytotoxic cascades in neurons (J. M. Lee et al., 2000). Accordingly, we examined $\mathrm{N}$-cadherin cleavage in vivo using ischemicreperfused mouse brain. In the ipsilateral hemisphere of a brain with focal cerebral ischemia, we observed the cleavage of spectrin ( $\alpha$-fordin) well known as calpain substrate, as previously reported (Kawamura et al., 2005). In addition, the NTF cleavage of $\mathrm{N}$-cadherin was clearly detectable. The cleavages of $\mathrm{N}$-cadherin and spectrin appeared prominent in the ischemic hemisphere, but not in the contralateral side of the brain or in the control brain (Fig. $3 A, B$ ).

To verify whether the cleavage of $\mathrm{N}$-cadherin is mediated by calpain in the ischemic brain, we examined the effect of the calpain inhibitor MDL 28170 in the ischemic brain. A potent calpain inhibitor, MDL 28170 rapidly penetrates the brain and inhibits calpain activity following its systemic administration, and it has been shown to reduce ischemic lesions in the rat brain (Markgraf et al., 1998). We also examined the protective effect of MDL 
A

Endocytosis

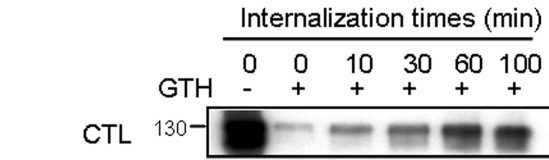

NMDA $20 \mu \mathrm{M}$

NMDA $300 \mu \mathrm{M}$

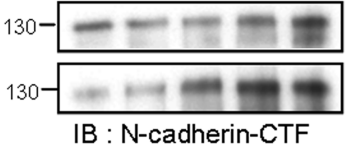

C

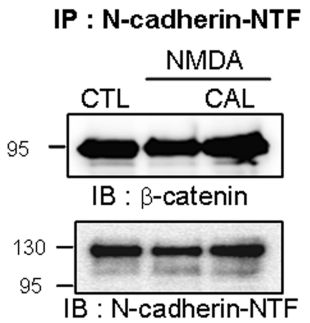

Surface

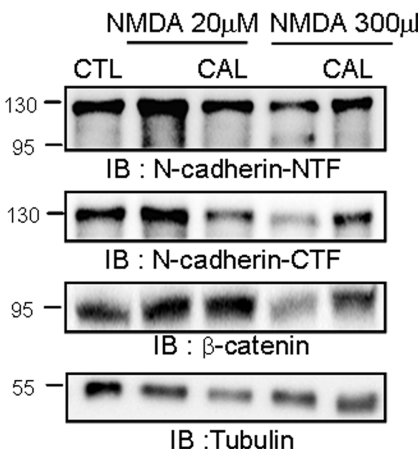

IB :Tubulin
$B$

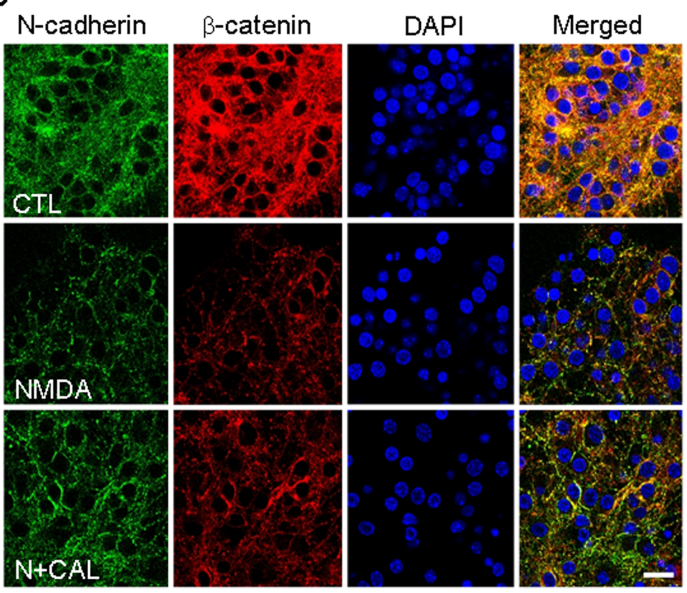

95

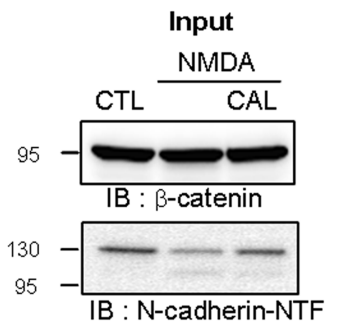

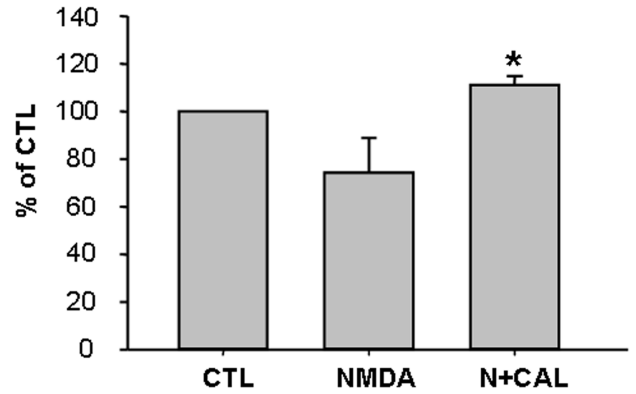

Figure 5. Alteration of surface $\mathrm{N}$-cadherin expression and $\mathrm{N}$-cadherin/ $\beta$-catenin interaction by calpain after NMDA stimulation. $A$, Endocytosis and surface expression of $\mathrm{N}$-cadherin in the treatment of 20 and $300 \mu \mathrm{m} \mathrm{NMDA}$. Treatment with $20 \mu \mathrm{m}$ NMDA was for 3 min; treatment of $300 \mu \mathrm{m}$ NMDA was for $30 \mathrm{~min}$. Four hours after NMDA treatment, surface proteins were analyzed by biotinylation. GTH, Glutathione. B, Calpain inhibitor prolonged cell surface expression of N-cadherin and $\beta$-catenin. The immunostaining was performed $1 \mathrm{~h}$ after NMDA (100 $\mu \mathrm{m}$ ) treatment. For detection of N-cadherin expression, N-cadherin-NTF antibody was used. Scale bar, $10 \mu \mathrm{m}$. C, Calpain inhibitor (CAL) potentiated the association between $\beta$-catenin and N-cadherin in cortical neurons. $\beta$-catenin was immunoprecipitated with N-cadherin-NTF antibody, followed by Western blot analysis. Values represent the mean \pm SEM ( ${ }^{*} p<0.05$ vs NMDA treatment).

28170 on ischemia-induced neuronal death. As shown in Figure $3 C$, administration of MDL 28170 significantly reduced infarct size, suggesting that calpain inhibition prevents ischemia-induced neuronal death. These data strongly supported that N-cadherin cleavage by calpain is associated with neuronal death; therefore calpain is a major target of prevention of neuronal death.

\section{Identification of the $\mathrm{N}$-cadherin cleavage sites}

To identify the calpain cleavage sites on $\mathrm{N}$-cadherin, we generated various C-terminal deletion mutants (Fig. 4A). First, we isolated membrane fractions from COS-7 cells expressing $\mathrm{N}$-cad $750,760,771,801,839$, or 906 (wild type) with calpain 5 construct. As previously reported (Reiss et al., 2005), MMP produced fragments indicated with asterisks and increased their molecular weight with increasing $\mathrm{N}$-cadherin intracellular domain, because they included the transmembrane and intracellular domain (Fig. $4 B, C)$.

Calpain digested $\mathrm{N}$-cadherin mutant $>771$ (Fig. $4 \mathrm{~B}$ ), indicating that the region between residue 760 and 771 is a cleavage site. In line with this observation, calpain produced one GFP-tagged fragment from $\mathrm{N}$-cad 771 (Fig. $4 \mathrm{~B}$, arrow in lane 3), indicating that region between residues 760 and 771 is a cleavage site. This cleaved $28 \mathrm{kDa}$ GFP-tagged cleaved fragment from the N-cad 771 mutant was shifted to $34 \mathrm{kDa}$ in the $\mathrm{N}$-cad 790 mutant (Fig. $4 \mathrm{~B}$, arrow in lane 4), and these fragments increased the length of the $\mathrm{N}$-cadherin constructs (Fig. $4 \mathrm{~B}$, arrows in lane 5 and 6). The different fragment was obtained from the N-cad 801 and 839 mutants (Fig. $4 B$, arrowheads lane 5 and 6), implicating that another cleavage site exists between residues 790 and 801 in $\mathrm{N}$-cadherin.

To further investigate the N-cadherin cleavage sites, we generated internal deletion mutants. We found possibilities for other cleavage sites. The band marked by a filled arrowhead in Figure $4 C$ was only present for the $\Delta 771-801$ mutant and undetectable with the $\Delta 771-839$ mutant, suggesting that a third cleavage site may reside between residues 801 and 839 in N-cadherin. In addition, a band of $\sim 34 \mathrm{kDa}$ was present for all deletion constructs (Fig. 4C, \&), indicating that a fourth cleavage site may be located between residues 839 and 906 . Together, our results demonstrate that calpain-recognized cleavage sites on $\mathrm{N}$-cadherin exist in at least four regions, residues $760-771,790-801,801-839$, and 839-906.

The intracellular fragment of $\mathrm{N}$-cadherin (CTF) is also known to be generated after the activation of MMP by ionomycin or NMDA treatment (Marambaud et al., 2003; Reiss et al., 2005; Uemura et al., 2006b). To identify which proteases are involved in NMDA-mediated CTF generation, we examined CTF production after NMDA treatment in the presence of specific inhibitors using the anti-intracellular $\mathrm{N}$-cadherin antibody. As expected, the MMP inhibitor 1, 10-phenanthroline reduced CTF generation in a dose-dependent manner (Fig. $4 D$, lanes 4 and 5). However, calpeptin markedly increased CTF generation compared with NMDA alone (Fig. 4D, lane 3). These results suggest that calpain inhibition protects further degradation of the CTF produced by the activation of MMP.

Degradation of cadherins is known to be dependent on the 
A

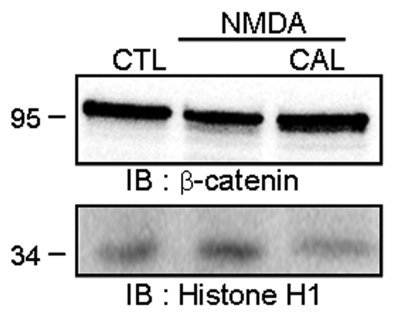

B

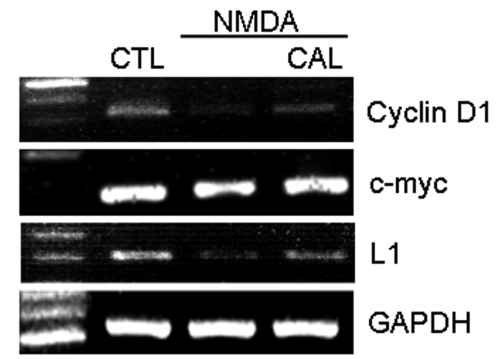

C

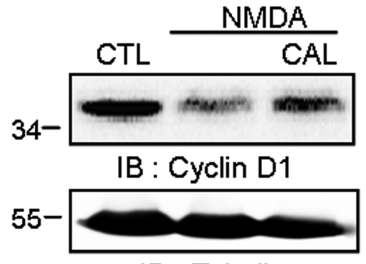

IB : Tubulin
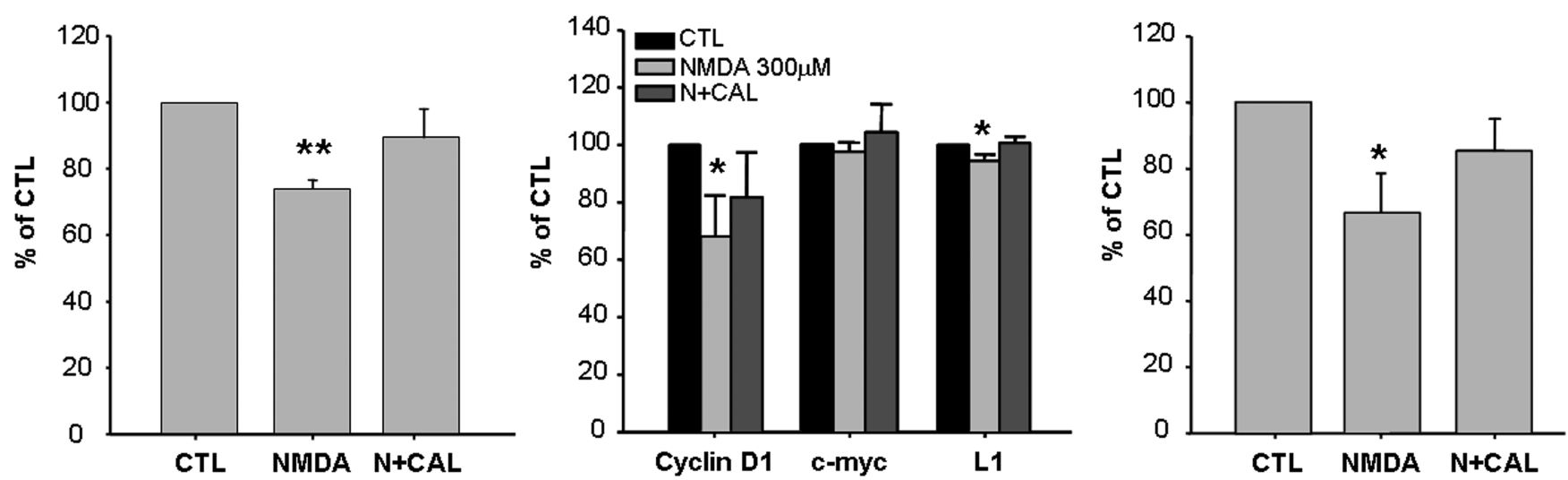

Figure 6. Nuclear $\beta$-catenin accumulation after calpain inhibition induces the expression of Wnt target genes. $\boldsymbol{A}$, Calpain inhibition resulted in nuclear $\beta$-catenin accumulation. Four hours after stimulation, the nucleus fraction was isolated. Histone $\mathrm{H} 1$ was used as the loading control for nuclear fractions. $\boldsymbol{B}$, Calpeptin (CAL) restored the expression of cyclin D1 and L1 mRNA reduced by 300 $\mu \mathrm{m}$ NMDA. $\boldsymbol{C}$, The patterns of cyclin D1 protein expression in cortical neurons $8 \mathrm{~h}$ after NMDA treatment. The bottom panels show the quantitative assessment of cyclin D1, $\boldsymbol{C}-\mathrm{myc}$, and L1 $\mathrm{mRNA}$ (B) and cyclin D1 protein (C). Values represent the mean \pm SEM ( ${ }^{*} p<0.05$ vs control, ${ }^{* *} p<0.01$ vs control).

ubiquitin/proteasome system (UPS) (Steinhusen et al., 2001; Vincent et al., 2004; Monea et al., 2006). Therefore, we tested whether calpain-mediated $\mathrm{N}$-cadherin cleavage is connected with the UPS. To investigate this idea, the proteasome inhibitor MG 115 was used to treat cortical neurons with NMDA or ionomycin (Fig. $4 E$ ). Treatment with MG 115 resulted in the accumulation of intracellular $29 \mathrm{kDa}$ and $27 \mathrm{kDa}$ fragments (Fig. $4 E$, asterisks), indicating that CTF degradation is dependent on the UPS. Together, these observations imply that the CTF of $\mathrm{N}$-cadherin is produced by MMP, and the resulting CTF is further cleaved by calpain and the proteasome system.

\footnotetext{
Alterations of surface $\mathrm{N}$-cadherin expression and $\mathrm{N}$-cadherin/ $\boldsymbol{\beta}$-catenin interaction by calpain after NMDA stimulation Activation of the NMDA receptor alters the rate of $\mathrm{N}$-cadherin endocytosis, resulting in the accumulation of $\mathrm{N}$-cadherin in the plasma membrane (Tai et al., 2007). To further investigate the above observations, we performed the surface biotinylation assay to detect $\mathrm{N}$-cadherin expression in the cell membrane. Treatment with $20 \mu \mathrm{M}$ NMDA decreased the endocytosis of $\mathrm{N}$-cadherin and resulted in increased $\mathrm{N}$-cadherin surface expression (Fig. 5A), in agreement with previous reports (Tai et al., 2007). However, treatment with $300 \mu \mathrm{M}$ NMDA evoked profound neuronal death and did not reduce the internalization rate (Fig. 5A). Neuronal death was not observed with $20 \mu \mathrm{M}$ NMDA and was shown from 50 $\mu \mathrm{M}$ NMDA (supplemental Fig. S3, available at www.jneurosci.org as supplemental material). The decrease in the surface expression of $\mathrm{N}$-cadherin after treatment with $300 \mu \mathrm{M}$ NMDA was accompanied by increased NTF generation, which was completely blocked by the calpain inhibitor calpeptin (Fig. $5 A$ ). In addition, the surface expression of $\beta$-catenin also was reduced by $300 \mu \mathrm{M}$ NMDA treatment but not $20 \mu \mathrm{M}$ NMDA (Fig. 5A). The calpain inhibitor calpeptin restored
}

completely the decreased surface expression of $\beta$-catenin by $300 \mu \mathrm{M}$ NMDA (Fig. 5A). In line with this result, the immunostaining of $\mathrm{N}$-cadherin and $\beta$-catenin was reduced by NMDA treatment and recovered by calpeptin (Fig. $5 B$ ), indicating that calpain modulates the surface expression of $\mathrm{N}$-cadherin together with $\beta$-catenin during NMDA excitotoxicity.

Next, we examined whether calpain influenced the formation of the $\mathrm{N}$-cadherin/ $\beta$-catenin complex. The $\beta$-catenin interaction with $\mathrm{N}$-cadherin was significantly increased in the presence of calpeptin (Fig. 5C). Together, these observations imply that calpain activation results in $\mathrm{N}$-cadherin cleavage, simultaneously cleaving $\beta$-catenin and subsequently disrupting the $\mathrm{N}$-cadherin/ $\beta$-catenin complex in the membrane.

\section{Nuclear $\boldsymbol{\beta}$-catenin accumulation after calpain inhibition induces the expression of Wnt target genes}

To elucidate the physiological relevance of calpain-mediated $\mathrm{N}$-cadherin cleavage, we tested whether calpain modulates $\beta$-catenin signaling. The $\beta$-catenin protein has been known to bind $\mathrm{T}$ cell transcription factor/lymphocyte enhancer-binding factors (TCF/LEFs). Thus, the complex activates the expression of Wnt target genes for cell survival (Nelson and Nusse, 2004). Accordingly, we measured the amount of nuclear $\beta$-catenin using the subcellular fractionation method. We found that the amount of nuclear $\beta$-catenin was markedly reduced after $300 \mu \mathrm{M}$ NMDA treatment, but it was recovered by calpeptin treatment (Fig. 6A). This observation implicates that calpeptin protected cytoplasmic $\beta$-catenin from its degradation, and then increased nuclear $\beta$-catenin translocation. Therefore, we analyzed the mRNA expression of Wnt target genes such as cyclin D1 (Tetsu and McCormick, 1999), c-myc (He et al., 1998), and neuronspecific L1 (Gavert et al., 2005). The calpeptin-induced nuclear 
A

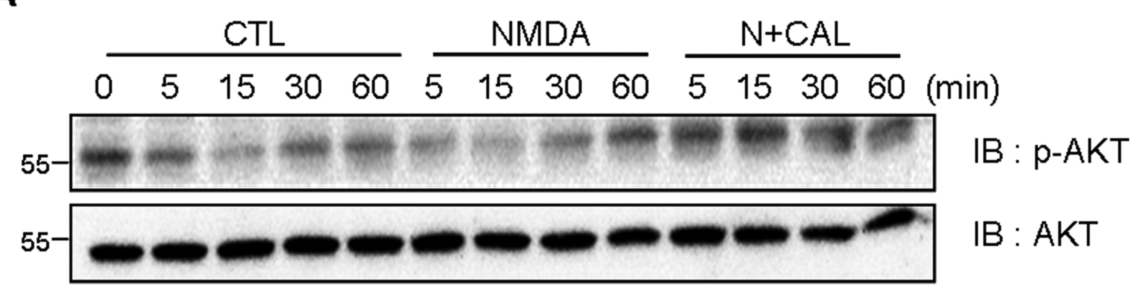

B

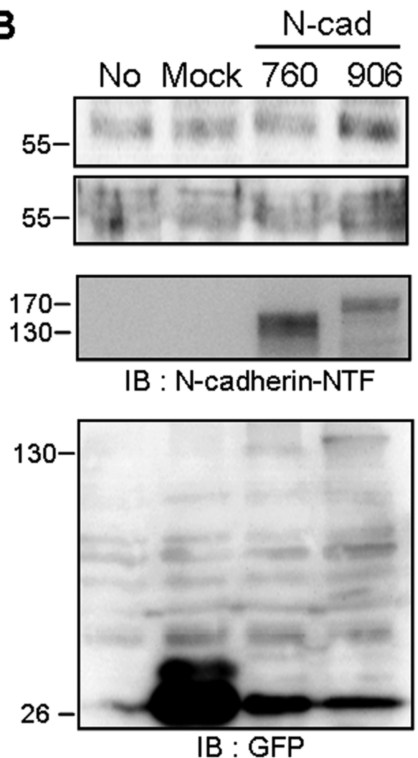

IB : p-AKT IB : AKT

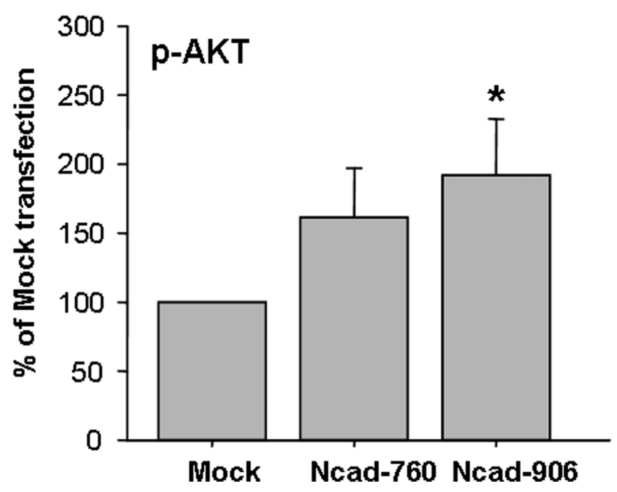

Figure 7. Expression and cleavage of N-cadherin regulates directly AKT signaling. $\boldsymbol{A}$, The level of pAKT expression during calpain inhibition in cortical neurons. Calpeptin enhanced AKT phosphorylation. $\boldsymbol{B}$, AKT phosphorylation in SK-N-MC cells transfected with $\mathrm{N}$-cadherin 760 ( $\mathrm{N}$-cad 760) and $\mathrm{N}$-cadherin 906 (N-cad 906). Values represent the mean $\pm \mathrm{SEM}$. ${ }^{*} p<0.05$ versus mock transfected cells.

$\beta$-catenin movement led to sustained levels of mRNA and protein expression for Wnt target genes for neuron survival (Fig. $6 B, C)$, demonstrating that calpain-mediated $\mathrm{N}$-cadherin cleavage modulates $\beta$-catenin signaling.

\section{Expression and cleavage of $\mathrm{N}$-cadherin regulates directly \\ AKT signaling}

Cadherin-directed cell adhesion plays a key role in the maintenance of membrane cell signaling, including PI3K/AKT (Tran et al., 2002). We examined whether AKT signaling was correlated with the calpain-mediated cleavage of $\mathrm{N}$-cadherin. As shown in Figure $7 A$, NMDA treatment reduced AKT phosphorylation, and calpeptin treatment potentiated these effects. This observation implies that NMDA-mediated N-cadherin cleavage might affect the activation of AKT.

To further demonstrate the direct effect of N-cadherin on AKT signaling, we observed AKT phosphorylation by transfection of N-cadherin constructs into SK-N-MC cells. SK$\mathrm{N}-\mathrm{MC}$ neuroblastoma cells expressed no endogenous $\mathrm{N}$-cadherin (Fig. $7 B$ ). As shown in Figure $7 B$, cells overexpressing wild-type $\mathrm{N}$-cadherin significantly increased p-AKT expression compared with mock transfected cells, but the $\mathrm{N}$-cad 760 mutant did not (Fig. $7 B$ ). These data indicate that $\mathrm{N}$-cadherin cleavage regulates AKT phosphorylation in calpain-dependent manner.

Calpain-mediated $\mathrm{N}$-cadherin cleavage inhibits cell-cell adhesion

Because cadherins play critical roles in the establishment of adherens-type junctions by mediating calcium-dependent cell-cell adhesion, calpain-mediated $\mathrm{N}$-cadherin cleavage may affect cell-cell adhesion. To address this, we performed a cell dissociation assay, illustrated with a diagram in Figure $8 \mathrm{~A}$. The extent of $\mathrm{N}$-cadherin expression might influence cell adhesion activity. In mouse myogenic $\mathrm{C} 2 \mathrm{C} 12$ cells, which have $\mathrm{N}$-cadherin-dependent adhesion (Gavard et al., 2004), we observed high adhesiveness in the control group (Fig. $8 B a, d$ ). Adhesion activity was represented by the index value, $\mathrm{N}_{\mathrm{TC}} / \mathrm{N}_{\mathrm{TE}}$, which was interpreted as representing increased cell adhesion activity at lower values. Ionomycin decreased cell adhesion in the presence of either TC or TE (Fig. $8 B b, e$ ), however calpeptin recovered the cell adhesion activity (Fig. $8 B c, f$ ). These results indicate that calpain modulates adhesion activity.

We were not able to use neurons because of difficulties in dissociating single cells by poly-D-lysine-coating. Instead of neurons, primary astrocytes expressing $\mathrm{N}$-cadherin (Kanemaru et al., 2007; Tran et al., 2008) and NMDA receptors (Serrano et al., 2008) were used. Regardless of the presence (TC treatment) or absence (TE treatment) of $\mathrm{Ca}^{2+}$, astrocytes were completely dissociated by NMDA treatment (Fig. 8C). As shown in Figure $8 C$, the index value was significantly lower after calpeptin treatment compared with NMDA alone, indicating that calpain inhibition increases adhesion activity. In addition, to confirm the effect of calpain on $\mathrm{N}$-cadherin-dependent adhesion, we used SK-N-MC neuroblastoma cells expressed no endogenous N-cadherin. The cells expressing wild type $\mathrm{N}$-cadherin $\mathrm{N}$-cad 906 had more adhesiveness than mock-transfected cells (Fig. $8 D$ ). In contrast, cells expressing $\mathrm{N}$-cad 760 mutant, which has no calpain target sites, were easier dissociated (Fig. $8 D$ ). Therefore, this mutant might act as a dominant negative mutant to preserve cell association. Together, our findings demonstrate that $\mathrm{N}$-cadherin cleavage by calpain suppressed $\mathrm{N}$-cadhein-mediated cell-cell adhesion.

Together, we found that calpain generates a novel $110 \mathrm{kDa}$ $\mathrm{N}$-terminal fragment (NTF) and several intracellular N-cadherin fragments in during NMDA- and ionomycin-induced cortical neurons and cerebral ischemic brain. These cleavages affected the $\mathrm{N}$-cadherin/ $\beta$-catenin interaction and, in turn, inhibited cellcell adhesion, AKT signaling, and nuclear $\beta$-catenin signaling. The results are summarized in Figure 9.

\section{Discussion}

Calpains, a well conserved family of calcium-dependent cysteine proteases, have been detected in the soma and synaptic terminal of neurons (Czogalla and Sikorski, 2005; Katsube et al., 2008). During synaptic activity, calpains are activated by calcium entry through NMDA receptors (Vanderklish et al., 1995). A number of calpain substrates have been identified, including cytoskeletal 
proteins, membrane proteins, adhesion molecules, kinases, and phosphatases (Rami, 2003). It has been reported that $\mathrm{N}$-cadherin is a substrate for a calciumactivated protease in chick brain homogenate (Covault et al., 1991). Our study provides direct evidence that $\mathrm{N}$-cadherin is a neuronal calpain substrate. The in vitro and in vivo calpain assays using $\mathrm{N}$-cadherin deletion mutants demonstrated that calpain is a specific protease for $\mathrm{N}$-cadherin cleavage, cutting in at least four regions of the cytoplasmic domain. Moreover, we suggest that calpainmediated cleavage may follow MMP- and $\gamma$-secretase-mediated $\mathrm{N}$-cadherin cleavage, and the resulting CTF is further degraded through the proteasome system. According to previous reports (Reiss et al., 2005; Uemura et al., 2006a), N-cad/CTF generated by ADAM 10 and $\gamma$-secretase translocates to the nucleus. However, in our immunostaining experiments, fragments of $\mathrm{N}$-cadherin were not detectable in the nucleus. Our result indicates that intracellular fragments of $\mathrm{N}$-cadherin produced by ADAM 10 and $\gamma$-secretase are not translocated to the nucleus because they are further degraded by calpain and the proteasome system.

The calpain system is known to be involved in $\beta$-catenin signaling regulation (Benetti et al., 2005; Abe and Takeichi, 2007). Calpain cleaves N-cadherin in the cytosolic domain, which is the site of $\beta$-catenin binding. Therefore, calpain activation during pathologic neurodegeneration decreases the expression of $\beta$-catenin, especially in the surface membrane. The instability of $\beta$-catenin is regulated by calpain rather than MMP and $\gamma$-secretase (Benetti et al., 2005; Abe and Takeichi, 2007). A decrease in $\beta$-catenin may not activate the expression of Wnt target genes, leading to diminished neuronal survival in Alzheimer's disease (De Ferrari et al., 2003).

It has been demonstrated that NMDA-dependent calpain activation results in the $\mathrm{N}$-terminal cleavage of $\beta$-catenin in hippocampal neurons (Abe and Takeichi, 2007). The $\beta$-catenin cleavage fragments accumulate in the nucleus and activate TCF-dependent gene transcription (Abe and Takeichi, 2007). This activity allows neurons to use $\beta$-catenin signaling for activitydependent gene expression (Staal et al., 2002). We also provide another role of calpain, neuronal activity-dependent and calpain-mediated $\mathrm{N}$-cadherin cleavage. Treatment with NMDA and ischemic insult cause the hyperactivation of calpain, which is implicated in several chronic neurodegenerative conditions, in-

TC-2mm

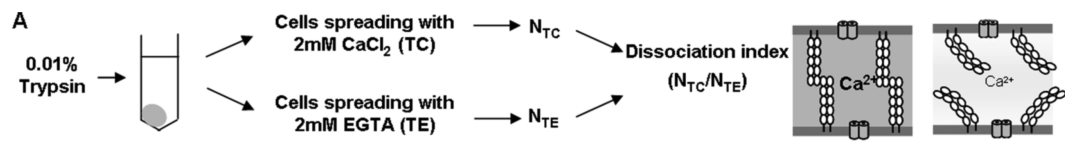

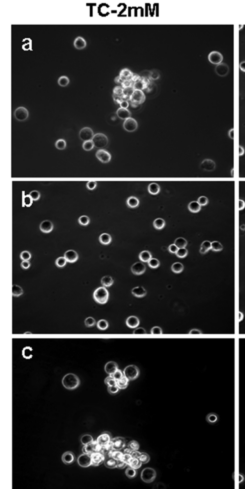

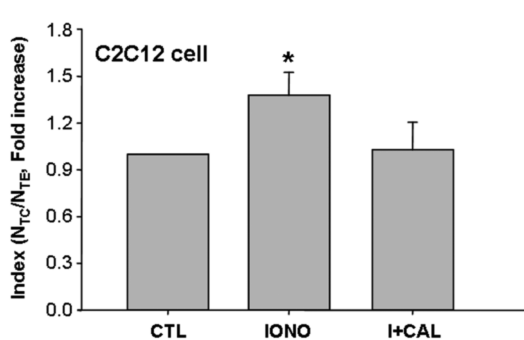

C

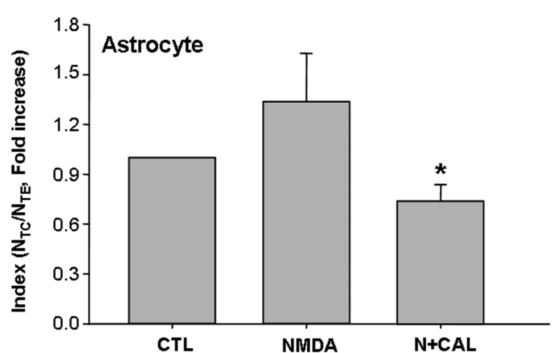

D

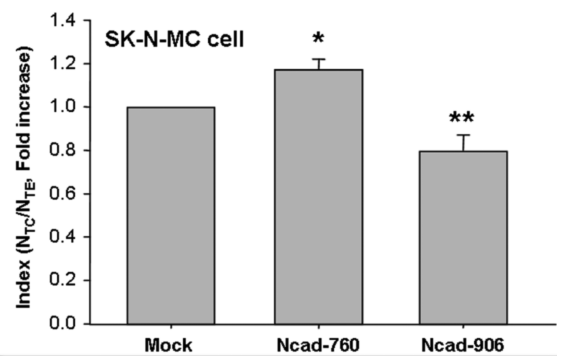

Figure 8. Calpain-mediated N-cadherin cleavage inhibits cell-cell adhesion. $A$, The procedures of the cell dissociation assay. $B$, The adhesion activity of $\mathrm{C} 2 \mathrm{C} 12$ cells. Ionomycin treatment resulted in dissociated cells, whereas calpeptin treatment increased cell association. $\boldsymbol{a}, \boldsymbol{d}$, Control; $\boldsymbol{b}, \boldsymbol{e}, 1 \mu \mathrm{m}$ ionomycin (IONO); $\boldsymbol{c}, \boldsymbol{f}, 1 \mu \mathrm{m}$ ionomycin plus $50 \mu \mathrm{m}$ calpeptin. Lower panels indicate the cell dissociation index $\left(\mathrm{N}_{\mathrm{TC}} / \mathrm{N}_{\mathrm{TE}}\right.$; see Materials and Methods). Scale bar, $100 \mu \mathrm{m}$. C, The adhesion activity of astrocytes. NMDA and calpain inhibitor ( $\mathrm{N}+\mathrm{CAL}$ ) was significantly reduced dissociation assay. $\boldsymbol{D}$, Adhesion activity of $\mathrm{N}$-cadherin constructs-transfected SK-N-MC cells. Values represent the mean \pm SEM. ${ }^{*} p<0.05$ versus control (CTL) in $B ;{ }^{*} p<0.05$ versus NMDA treatment in $\boldsymbol{C}$; ${ }^{*} p<0.05$ versus mock transfected cells, ${ }^{* *} p<0.01$ versus mock transfected cells in $\boldsymbol{D}$.

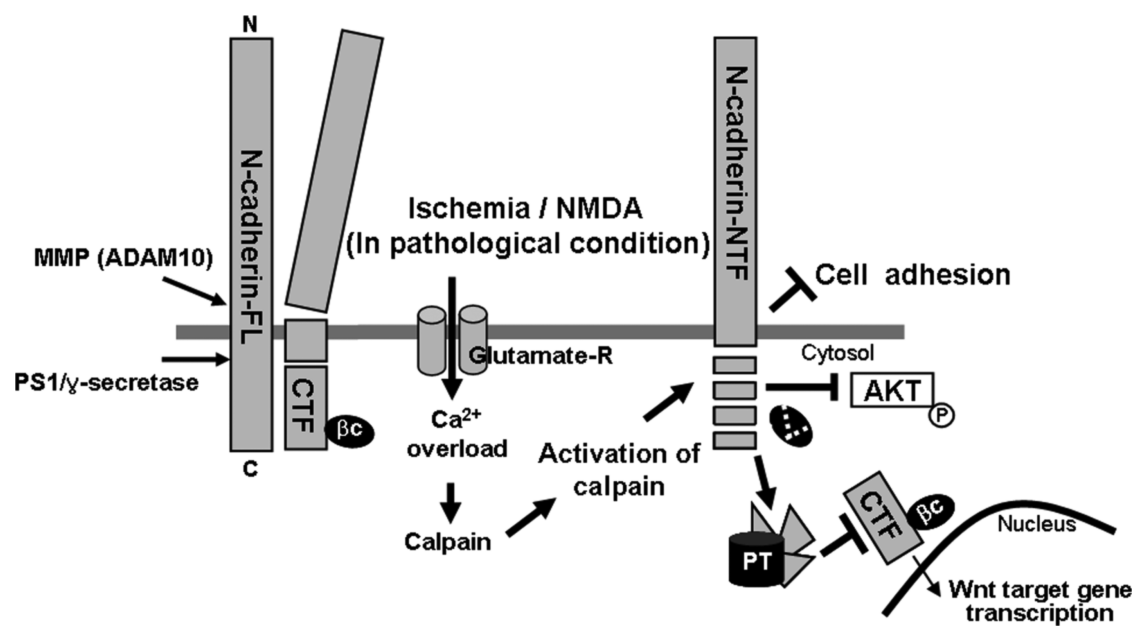

Figure 9. A model of $\mathrm{N}$-cadherin cleavage. The MMP (ADAM 10) and PS1/ $\gamma$-secretase cleaved N-cadherin and resulted in CTF generation, previously reported (Marambaud et al., 2003; Reiss et al., 2005). In pathological conditions such as ischemia or NMDA excitotoxicity, excess influx of $\mathrm{Ca}^{2+}$ through NMDA receptor activates calcium-dependent protease, calpain. Activation of calpain induces cleavage of $\mathrm{N}$-cadherin in the cytoplasmic domain, resulting in generation of $\mathrm{N}$-cadherin NTF, and disruption of $\mathrm{N}$-cadherin/ $\beta$-catenin complex. The cleaved fragments are further degraded by proteasome, which prevents nuclear translocation of $\mathrm{CTF}$, AKT phosphorylation, and cell adhesion. According to our results, roles of calpain-mediated N-cadherin cleavage during neurodegeneration were represented with thick arrows and line in this figure. PT, Proteasome; $F L$, full length; $\beta C, \beta$-catenin.

cluding Alzheimer's disease, Parkinson's disease, and Huntington's disease (Liu et al., 2008). Our in vivo ischemic study also showed that calpain-mediated $\mathrm{N}$-cadherin cleavage and loss of $\beta$-catenin was associated with neuronal death. 
In the present study, NMDA receptor hyperactivation by NMDA treatment and ischemic insult also induced prominent $\beta$-catenin cleavage. Accordingly, it is possible that pathological injuries induce the degradation of $\mathrm{N}$-cadherin and $\beta$-catenin in the cytoplasm, weaken nuclear $\beta$-catenin translocation, and ultimately reduce TCF/LEFs-dependent gene expression for neuronal survival (Fig. 6). Consequently, the stability of $\beta$-catenin, which is also regulated by calpain, is necessary for neuronal survival. Actually, we investigated neuronal death under different concentrations of NMDA using MTT assay. The neuronal death did not occur in $20 \mu \mathrm{M}$ NMDA but began from $50 \mu \mathrm{M}$ NMDA (supplemental Fig. S3, available at www.jneurosci.org as supplemental material). The $\beta$-catenin also acted differently in high dose of NMDA inducing cell death, compared with activitydependent physiological NMDA dosage $(20 \mu \mathrm{M})$. Therefore, the activation of calpain by calcium influx through NMDA receptor might determine whether neuronal survival or death through modulation of $\mathrm{N}$-cadherin and $\beta$-catenin cleavages.

The surface expression of $\mathrm{N}$-cadherin is important for cellular maintenance and survival including normal synaptic function, and is regulated by endocytosis (Yap et al., 2007). Activation of NMDA receptor plays roles in the regulation of gene expression in activity-dependent manner. NMDA also regulates the surface expression of $\mathrm{N}$-cadherin by modulation of the internalization rate (Tai et al., 2007). Treatment with $20 \mu \mathrm{M}$ NMDA reduced the internalization rate of $\mathrm{N}$-cadherin and slightly increased the surface expression of $\mathrm{N}$-cadherin; in contrast with $300 \mu \mathrm{M}$ NMDA, the surface expression of $\mathrm{N}$-cadherin decreased because of increased cleavage by calpain, not change in endocytosis as internalization did not decrease. This discrepancy might be caused by different activities of calpain in different dose of NMDA. In pathological condition such as NMDA excitotoxicity, excessive $\mathrm{Ca}^{2+}$ influx induces hyperactivation of calpain and finally determines the neuronal fate associated with $\mathrm{N}$-cadherin cleavage.

The adhesive function of cadherins depends on a stable connection with the actin cytoskeleton via $\beta$-catenin (Chu et al., 2006; Siu et al., 2007). The cytoplasmic tail in the juxtamembrane region of the cadherin is known as a functionally active adaptor supporting cadherin clustering and adhesive strength (Yap et al., 1998). The stability of $\beta$-catenin can also cause resistance against apoptosis (Fiorentino et al., 2008). In the present study, calpain activated by NMDA cleaved $\mathrm{N}$-cadherin and also reduced the interaction with $\mathrm{N}$-cadherin and $\beta$-catenin. Decreased interaction leads to a loss of cell-cell adhesion in cortical neurons (Kwon et al., 2000). Similar to this report, we elucidated the role of $\mathrm{N}$-cadherin and calpain in cell-cell adhesion. Because the structure of the extracellular domain of $\mathrm{N}$-cadherin is highly $\mathrm{Ca}^{2+}$-dependent, reductions in $\mathrm{Ca}^{2+}$ levels might destabilize cadherin bonds (Murase and Schuman, 1999). The adhesion activity of cells transfected with the N-cad 760 mutant was significantly reduced. These findings reflect that amino acid residues 760-771 are an important cleavage site in N-cadherin; thus, calpain-mediated $\mathrm{N}$-cadherin proteolysis prevents $\beta$-catenin from binding to $\mathrm{N}$-cadherin. Our data suggest that calpainmediated $\mathrm{N}$-cadherin cleavage represents a potent mechanism for the regulation of cell-cell adhesion.

Expression and stabilization of $\mathrm{N}$-cadherin is important for cell adhesion, which promotes cell survival via phosphoinositide-3 kinase (PI3K)/AKT signaling (Li et al., 2001; Tran et al., 2002). N-cadherin forms a complex with PI3K beneath the plasma membrane; therefore, their complex activates AKT (Tran et al., 2002). Presenilin (PS) 1, a causative gene product of familial Alzheimer's disease also interacts with N-cadherin/ $\beta$-catenin complex, and the complex modulates PI3K/AKT signaling (Baki et al., 2004; Uemura et al., 2007). Our observations also showed that AKT signaling is regulated by N-cadherin expression or cleavage, which might be involved in cell survival.

In summary, we present direct evidence that calpain mediates $\mathrm{N}$-cadherin cleavage in ischemic or excitotoxic neurodegeneration. N-cadherin expression can regulate cell-cell adhesion and $\mathrm{AKT}$, which is regulated by calpain-mediated cleavage. In addition, calpain-mediated cleavage of $\mathrm{N}$-cadherin and $\beta$-catenin affects their complex and nuclear $\beta$-catenin signaling.

\section{References}

Abe K, Takeichi M (2007) NMDA-receptor activation induces calpainmediated beta-catenin cleavages for triggering gene expression. Neuron 53:387-397.

Baki L, Shioi J, Wen P, Shao Z, Schwarzman A, Gama-Sosa M, Neve R, Robakis NK (2004) PS1 activates PI3K thus inhibiting GSK-3 activity and tau overphosphorylation: effects of FAD mutations. EMBO J 23:2586-2596.

Benetti R, Copetti T, Dell'Orso S, Melloni E, Brancolini C, Monte M, Schneider C (2005) The calpain system is involved in the constitutive regulation of beta-catenin signaling functions. J Biol Chem 280:22070-22080.

Boldyrev AA (2000) Functional interaction between various glutamate receptors. Bull Exp Biol Med 130:823-829.

Chu YS, Eder O, Thomas WA, Simcha I, Pincet F, Ben-Ze'ev A, Perez E, Thiery JP, Dufour S (2006) Prototypical type I E-cadherin and type II cadherin-7 mediate very distinct adhesiveness through their extracellular domains. J Biol Chem 281:2901-2910.

Covault J, Liu QY, el-Deeb S (1991) Calcium-activated proteolysis of intracellular domains in the cell adhesion molecules NCAM and N-cadherin. Brain Res Mol Brain Res 11:11-16.

Crocker SJ, Smith PD, Jackson-Lewis V, Lamba WR, Hayley SP, Grimm E, Callaghan SM, Slack RS, Melloni E, Przedborski S, Robertson GS, Anisman H, Merali Z, Park DS (2003) Inhibition of calpains prevents neuronal and behavioral deficits in an MPTP mouse model of Parkinson's disease. J Neurosci 23:4081-4091.

Czogalla A, Sikorski AF (2005) Spectrin and calpain: a 'target' and a 'sniper' in the pathology of neuronal cells. Cell Mol Life Sci 62:1913-1924.

De Ferrari GV, Chacón MA, Barría MI, Garrido JL, Godoy JA, Olivares G, Reyes AE, Alvarez A, Bronfman M, Inestrosa NC (2003) Activation of Wnt signaling rescues neurodegeneration and behavioral impairments induced by beta-amyloid fibrils. Mol Psychiatry 8:195-208.

Fiorentino M, Zadra G, Palescandolo E, Fedele G, Bailey D, Fiore C, Nguyen PL, Migita T, Zamponi R, Di Vizio D, Priolo C, Sharma C, Xie W, Hemler ME, Mucci L, Giovannucci E, Finn S, Loda M (2008) Overexpression of fatty acid synthase is associated with palmitoylation of Wntl and cytoplasmic stabilization of beta-catenin in prostate cancer. Lab Invest 88:1340-1348.

Fukata M, Nakagawa M, Kuroda S, Kaibuchi K (2002) Effects of Rho family GTPases on cell-cell adhesion. Methods Mol Biol 189:121-128.

Gavard J, Lambert M, Grosheva I, Marthiens V, Irinopoulou T, Riou JF, Bershadsky A, Mège RM (2004) Lamellipodium extension and cadherin adhesion: two cell responses to cadherin activation relying on distinct signalling pathways. J Cell Sci 117:257-270.

Gavert N, Conacci-Sorrell M, Gast D, Schneider A, Altevogt P, Brabletz T, Ben-Ze'ev A (2005) L1, a novel target of beta-catenin signaling, transforms cells and is expressed at the invasive front of colon cancers. J Cell Biol 168:633-642.

Hara H, Ayata C, Huang PL, Waeber C, Ayata G, Fujii M, Moskowitz MA (1997) [ $\left.{ }^{3} \mathrm{H}\right] \mathrm{L}-\mathrm{NG}$-nitroarginine binding after transient focal ischemia and NMDA-induced excitotoxicity in type I and type III nitric oxide synthase null mice. J Cereb Blood Flow Metab 17:515-526.

He TC, Sparks AB, Rago C, Hermeking H, Zawel L, da Costa LT, Morin PJ, Vogelstein B, Kinzler KW (1998) Identification of c-MYC as a target of the APC pathway. Science 281:1509-1512.

Inoue A, Sanes JR (1997) Lamina-specific connectivity in the brain: regulation by N-cadherin, neurotrophins, and glycoconjugates. Science 276:1428-1431.

Jin RL, Li WB, Li QJ, Zhang M, Xian XH, Sun XC, Zhao HG, Qi J (2006) The role of extracellular signal-regulated kinases in the neuroprotection of limb ischemic preconditioning. Neurosci Res 55:65-73. 
Kanemaru K, Okubo Y, Hirose K, Iino M (2007) Regulation of neurite growth by spontaneous $\mathrm{Ca} 2+$ oscillations in astrocytes. J Neurosci 27:8957-8966.

Katsube M, Kato T, Kitagawa M, Noma H, Fujita H, Kitagawa S (2008) Calpain-mediated regulation of the distinct signaling pathways and cell migration in human neutrophils. J Leukoc Biol 84:255-263.

Kawamura M, Nakajima W, Ishida A, Ohmura A, Miura S, Takada G (2005) Calpain inhibitor MDL 28170 protects hypoxic-ischemic brain injury in neonatal rats by inhibition of both apoptosis and necrosis. Brain Res 1037:59-69.

Kusakawa G, Saito T, Onuki R, Ishiguro K, Kishimoto T, Hisanaga S (2000) Calpain-dependent proteolytic cleavage of the p35 cyclin-dependent kinase 5 activator to p25. J Biol Chem 275:17166-17172.

Kwon KJ, Jung YS, Lee SH, Moon CH, Baik EJ (2005) Arachidonic acid induces neuronal death through lipoxygenase and cytochrome P450 rather than cyclooxygenase. J Neurosci Res 81:73-84.

Kwon YT, Gupta A, Zhou Y, Nikolic M, Tsai LH (2000) Regulation of $\mathrm{N}$-cadherin-mediated adhesion by the p35-Cdk5 kinase. Curr Biol 10:363-372.

Lankiewicz S, Marc Luetjens C, Truc Bui N, Krohn AJ, Poppe M, Cole GM, Saido TC, Prehn JH (2000) Activation of calpain I converts excitotoxic neuron death into a caspase-independent cell death. J Biol Chem 275:17064-17071.

Lee JH, Lee EO, Kang JL, Chong YH (2008) Concomitant degradation of betacatenin and GSK-3 beta potently contributes to glutamate-induced neurotoxicity in rat hippocampal slice cultures. J Neurochem 106:1066-1077.

Lee JM, Grabb MC, Zipfel GJ, Choi DW (2000) Brain tissue responses to ischemia. J Clin Invest 106:723-731.

Lee MS, Kwon YT, Li M, Peng J, Friedlander RM, Tsai LH (2000) Neurotoxicity induces cleavage of p35 to p25 by calpain. Nature 405:360-364.

Li G, Satyamoorthy K, Herlyn M (2001) N-cadherin-mediated intercellular interactions promote survival and migration of melanoma cells. Cancer Res 61:3819-3825.

Liu J, Liu MC, Wang KK (2008) Calpain in the CNS: from synaptic function to neurotoxicity. Sci Signal 1:re1.

Longa EZ, Weinstein PR, Carlson S, Cummins R (1989) Reversible middle cerebral artery occlusion without craniectomy in rats. Stroke 20:84-91.

Marambaud P, Wen PH, Dutt A, Shioi J, Takashima A, Siman R, Robakis NK (2003) A CBP binding transcriptional repressor produced by the PS1/ epsilon-cleavage of N-cadherin is inhibited by PS1 FAD mutations. Cell 114:635-645.

Markgraf CG, Velayo NL, Johnson MP, McCarty DR, Medhi S, Koehl JR, Chmielewski PA, Linnik MD (1998) Six-hour window of opportunity for calpain inhibition in focal cerebral ischemia in rats. Stroke 29:152-158.

Matsunaga M, Hatta K, Nagafuchi A, Takeichi M (1988) Guidance of optic nerve fibres by $\mathrm{N}$-cadherin adhesion molecules. Nature 334:62-64

Monea S, Jordan BA, Srivastava S, DeSouza S, Ziff EB (2006) Membrane localization of membrane type 5 matrix metalloproteinase by AMPA receptor binding protein and cleavage of cadherins. J Neurosci 26:2300-2312.

Murase S, Schuman EM (1999) The role of cell adhesion molecules in synaptic plasticity and memory. Curr Opin Cell Biol 11:549-553.

Nagafuchi A, Ishihara S, Tsukita S (1994) The roles of catenins in the cadherin-mediated cell adhesion: functional analysis of E-cadherin-alpha catenin fusion molecules. J Cell Biol 127:235-245.

Nelson WJ, Nusse R (2004) Convergence of Wnt, beta-catenin, and cadherin pathways. Science 303:1483-1487.

Okabe T, Nakamura T, Nishimura YN, Kohu K, Ohwada S, Morishita Y, Akiyama T (2003) RICS, a novel GTPase-activating protein for Cdc42 and Racl, is involved in the beta-catenin-N-cadherin and N-methyl-Daspartate receptor signaling. J Biol Chem 278:9920-9927.

Parisiadou L, Fassa A, Fotinopoulou A, Bethani I, Efthimiopoulos S (2004) Presenilin 1 and cadherins: stabilization of cell-cell adhesion and proteolysis-dependent regulation of transcription. Neurodegener Dis 1:184-191.

Patrick GN, Zukerberg L, Nikolic M, de la Monte S, Dikkes P, Tsai LH (1999) Conversion of p35 to p 25 deregulates Cdk5 activity and promotes neurodegeneration. Nature 402:615-622.

Patzke H, Tsai LH (2002) Calpain-mediated cleavage of the cyclindependent kinase-5 activator p39 to p29. J Biol Chem 277:8054-8060.

Rami A (2003) Ischemic neuronal death in the rat hippocampus: the calpain-calpastatin-caspase hypothesis. Neurobiol Dis 13:75-88.
Reiss K, Maretzky T, Ludwig A, Tousseyn T, de Strooper B, Hartmann D, Saftig P (2005) ADAM10 cleavage of N-cadherin and regulation of cellcell adhesion and beta-catenin nuclear signalling. EMBO J 24:742-752.

Rios-Doria J, Day ML (2005) Truncated E-cadherin potentiates cell death in prostate epithelial cells. Prostate 63:259-268.

Saito K, Elce JS, Hamos JE, Nixon RA (1993) Widespread activation of calcium-activated neutral proteinase (calpain) in the brain in Alzheimer disease: a potential molecular basis for neuronal degeneration. Proc Natl Acad Sci U S A 90:2628-2632.

Serrano A, Robitaille R, Lacaille JC (2008) Differential NMDA-dependent activation of glial cells in mouse hippocampus. Glia 56:1648-1663.

Siman R, Noszek JC, Kegerise C (1989) Calpain I activation is specifically related to excitatory amino acid induction of hippocampal damage. J Neurosci 9:1579-1590.

Siu R, Fladd C, Rotin D (2007) N-cadherin is an in vivo substrate for protein tyrosine phosphatase sigma (PTPsigma) and participates in PTPsigmamediated inhibition of axon growth. Mol Cell Biol 27:208-219.

Staal FJ, Noort Mv M, Strous GJ, Clevers HC (2002) Wnt signals are transmitted through $\mathrm{N}$-terminally dephosphorylated beta-catenin. EMBO Rep 3:63-68.

Steinhusen U, Weiske J, Badock V, Tauber R, Bommert K, Huber O (2001) Cleavage and shedding of E-cadherin after induction of apoptosis. J Biol Chem 276:4972-4980.

Strong MJ, Strong WL, Jaffe H, Traggert B, Sopper MM, Pant HC (2001) Phosphorylation state of the native high-molecular-weight neurofilament subunit protein from cervical spinal cord in sporadic amyotrophic lateral sclerosis. J Neurochem 76:1315-1325.

Tai CY, Mysore SP, Chiu C, Schuman EM (2007) Activity-regulated N-cadherin endocytosis. Neuron 54:771-785.

Takeichi M (1990) Cadherins: a molecular family important in selective cell-cell adhesion. Annu Rev Biochem 59:237-252.

Tetsu O, McCormick F (1999) Beta-catenin regulates expression of cyclin D1 in colon carcinoma cells. Nature 398:422-426.

Tomimatsu Y, Idemoto S, Moriguchi S, Watanabe S, Nakanishi H (2002) Proteases involved in long-term potentiation. Life Sci 72:355-361.

Tran MD, Wanner IB, Neary JT (2008) Purinergic receptor signaling regulates $\mathrm{N}$-cadherin expression in primary astrocyte cultures. J Neurochem 105:272-286.

Tran NL, Adams DG, Vaillancourt RR, Heimark RL (2002) Signal transduction from N-cadherin increases Bcl-2. Regulation of the phosphatidylinositol 3-kinase/Akt pathway by homophilic adhesion and actin cytoskeletal organization. J Biol Chem 277:32905-32914.

Uemura K, Kihara T, Kuzuya A, Okawa K, Nishimoto T, Bito H, Ninomiya H, Sugimoto H, Kinoshita A, Shimohama S (2006a) Activity-dependent regulation of beta-catenin via epsilon-cleavage of $\mathrm{N}$-cadherin. Biochem Biophys Res Commun 345:951-958.

Uemura K, Kihara T, Kuzuya A, Okawa K, Nishimoto T, Ninomiya H, Sugimoto H, Kinoshita A, Shimohama S (2006b) Characterization of sequential N-cadherin cleavage by ADAM10 and PS1. Neurosci Lett 402:278-283.

Uemura K, Kuzuya A, Shimozono Y, Aoyagi N, Ando K, Shimohama S, Kinoshita A (2007) GSK3beta activity modifies the localization and function of presenilin 1. J Biol Chem 282:15823-15832.

Vanderklish P, Saido TC, Gall C, Arai A, Lynch G (1995) Proteolysis of spectrin by calpain accompanies theta-burst stimulation in cultured hippocampal slices. Brain Res Mol Brain Res 32:25-35.

Vanderklish PW, Bahr BA (2000) The pathogenic activation of calpain: a marker and mediator of cellular toxicity and disease states. Int J Exp Pathol 81:323-339.

Vincent PA, Xiao K, Buckley KM, Kowalczyk AP (2004) VE-cadherin: adhesion at arm's length. Am J Physiol Cell Physiol 286:C987-C997.

Wang KK, Larner SF, Robinson G, Hayes RL (2006) Neuroprotection targets after traumatic brain injury. Curr Opin Neurol 19:514-519.

Wang Y, White MG, Akay C, Chodroff RA, Robinson J, Lindl KA, Dichter MA, Qian Y, Mao Z, Kolson DL, Jordan-Sciutto KL (2007) Activation of cyclin-dependent kinase 5 by calpains contributes to human immunodeficiency virus-induced neurotoxicity. J Neurochem 103:439-455.

Yap AS, Niessen CM, Gumbiner BM (1998) The juxtamembrane region of the cadherin cytoplasmic tail supports lateral clustering, adhesive strengthening, and interaction with p120ctn. J Cell Biol 141:779-789.

Yap AS, Crampton MS, Hardin J (2007) Making and breaking contacts: the cellular biology of cadherin regulation. Curr Opin Cell Biol 19:508-514. 